Article

\title{
Biofuel Application as a Factor of Sustainable Development Ensuring: The Case of Russia
}

\author{
Ekaterina S. Titova \\ Federal Research Centre «Fundamentals of Biotechnology» of the Russian Academy of Sciences, \\ Leninsky Prospect, 33, bld. 2, 119071 Moscow, Russia; es_titova@inbox.ru
}

Received: 24 September 2019; Accepted: 15 October 2019; Published: 17 October 2019

check for updates

\begin{abstract}
Diffusion of the biofuels (BF) using is justified by opening up the opportunities for obtaining fuel and energy from previously inaccessible sources and by the existence of energy-deficient regions, in particular in Russia. Works of different scientists on the problems of creating and using BF were the methodological basis of this study. Information on the state and prospects of the development of renewable energy sources in Russian regions was collected from regulatory documents and was obtained by employing a questionnaire survey. For the study of the collected materials, the different methods of comparative analysis, and the methods of expert assessments were used. The results of the Status-Quo analysis of BF production in Russia have shown that the creation of BF performed relatively successfully. However, there are many more perspectives, connected with expanding the utilization of the different raw materials. Also, the analysis of organizational and economic mechanisms applied for production of BF and the obtained data on several organizations-producers allowed for proposing six indexes for the assessment of the BF production effectiveness. It is suggested that BF production in Russia will contribute to the sustainable development of a number of the country's regions in the near future.
\end{abstract}

Keywords: biofuel; risk analysis; sustainable development; renewable energy; biomass; biotechnology; anthropogenic waste processing; energy resource assessment

\section{Introduction}

The power supply is one of the most critical factors for sustainable development both for particular countries and for the global economy as a whole. In this vein, the UN sets seventeen main targets for the provision of sustainable development of all countries of the world and "cheap and clean energy" is number seven in this list [1]. Among the problems requiring a solution to achieve this target is an increase the share of clean energy and accessibility of technologies of its production using renewable energy (REn). Intensive application of conventional energy over decades had a negative impact on the environment and those linked with it have established additional conditions for comprehensive development of REn in different regions of the world. At the same time, the concept of sustainable state development comprises continuous and complete work for the improvement of the existing social and economic setup. That is why the application of REn is promising for an increase in the share of clean energy in the economy that produced employing innovative technologies, which will assist in solving this problem too. For instance, in 2018, considered to be the first in the world, the REn sector of Germany produced more energy than coal and more than $40 \%$ of the electricity generated throughout the year was created using of REn [2]. In Russia, the energy sector operation is historically based on hydrocarbons crude, as well as on hydro- and nuclear power stations.

Moreover, Russia is one of the leading suppliers of hydrocarbons in the global market. These circumstances significantly influence the perception of green energy production and general use of REn in the country. However, in the second decade of the 21st century, the environmental 
impact of permanent anthropogenic factors has required the taking of appropriate measures in this field both at the federal and regional levels. In particular, the accumulation of industrial, agricultural, and household wastes is becoming an essential incentive for the development of innovative activities aiming at the production of biofuel (BF). According to the existing data [3], the resource potential of recyclable organic waste biomass, including solid household wastes and sediments of wastewaters reaches 13,490.26 tons of coal equivalent (TCE) per year in Russia. This study led both at the federal level and in particular regions which have significant differences in terms of economic, geographic, and climatic conditions.

According to pessimistic forecasts, the share of green energy in the Russian economy will arrive at $3-5 \%$ by 2035 , according to positive ones, it will be equal to $8-10 \%$. The proposed share of BF in the production of electric and heat energy with targeted management could be about $2-3 \%$ [4].

Different geographic, climatic, economic, and other conditions in regions of Russia necessitate solving several scientific problems for optimization of the existing regional programs for the provision of sustainable development and determination of the role of REn and BF production in them.

Therefore, the progress in BF production achieved in some leading countries has become a significant factor which causes a positive impact on the sustainable development of their economies. This gives rise to the suggestion that Russia has some conditions for a more extensive application of REn, in particular, for BF production and use. Correspondingly, this article characterizes some general trends of BF production development and presents the results of the analysis of organizational and economic indexes of BF actual production in Russia as well as some data about planned production. The potential risks of BF production in the Russian Federation are also analyzed.

\section{Materials and Methods}

The global trends of BF production development, as well as stimulating institutional measures, were mainly analyzed using the works conducted in the leading countries in 2015-2019. BF production capabilities in Russia were analyzed using the published official documents of ministries and agencies, official reports of the Government and ministries, and business enterprises. Information on 74 Russian state and private enterprises involved in BF production or planning to start such production were gathered. Also, the information gathering was conducted by using a questionnaire survey-the questionnaires compiled by recommendations and with consideration of data of other authors [5-8]. The questionnaires contained 20 questions including (i) form of entity; (ii) date of commencement (planned commencement) of BF production; (iii) types of BF produced by the enterprise; (iv) raw materials used for BF production; (v) education level of employees; (vi) type of equipment used for BF production; (vii) sales of produced BF, etc. The questionnaire survey was conducted via e-mail as well as online and offline [9]. Also, the materials of publicly available databases accumulating information on the application of REn in production, such as IRENA.org [10-12], REN21.com [13], GIS RESR [3], etc. were used in work.

Russia possesses ample natural resources, including conventional energy sources. Hence, forecasting of BF production requires the development of different approaches and a set of tools for an unbiased assessment. It is worth noting that geographic, climatic, and economic conditions of Russian regions are substantially different. Due to this, a situational analysis was conducted in this work using the Russian regulatory documents, which are quoted below.

Based on obtained results, possible tools for assessment of BF production development were set out with the determination of several indexes and calculation manners. Relevant management measures for the provision of long-term BF production were elaborated. For setting out of the tools, the "before and after" conditions comparison method was used [14], as well as the contemporary methodology of Global Innovation Index [15-17], National Report on Innovations in Russia [18], some materials from publications on innovation management [19-23] were taken into account. Based on proposed tools with the using of grouping and determination methods [24-26], potential risks have been estimated. Risk assessment was performed using the method of E. Kulikova [27]. Based on the performed analysis, 
using the method of expert estimations, tendency function, and least square method, the estimated forecast of BF production development in Russia was formulated. Through the exploratory forecast method and using the theoretical basis of Russian and foreign scientists [28,29], possible conditions and future continuations of the found trends of BF production determined. Generally, the study algorithm included six main steps presented in Figure 1.

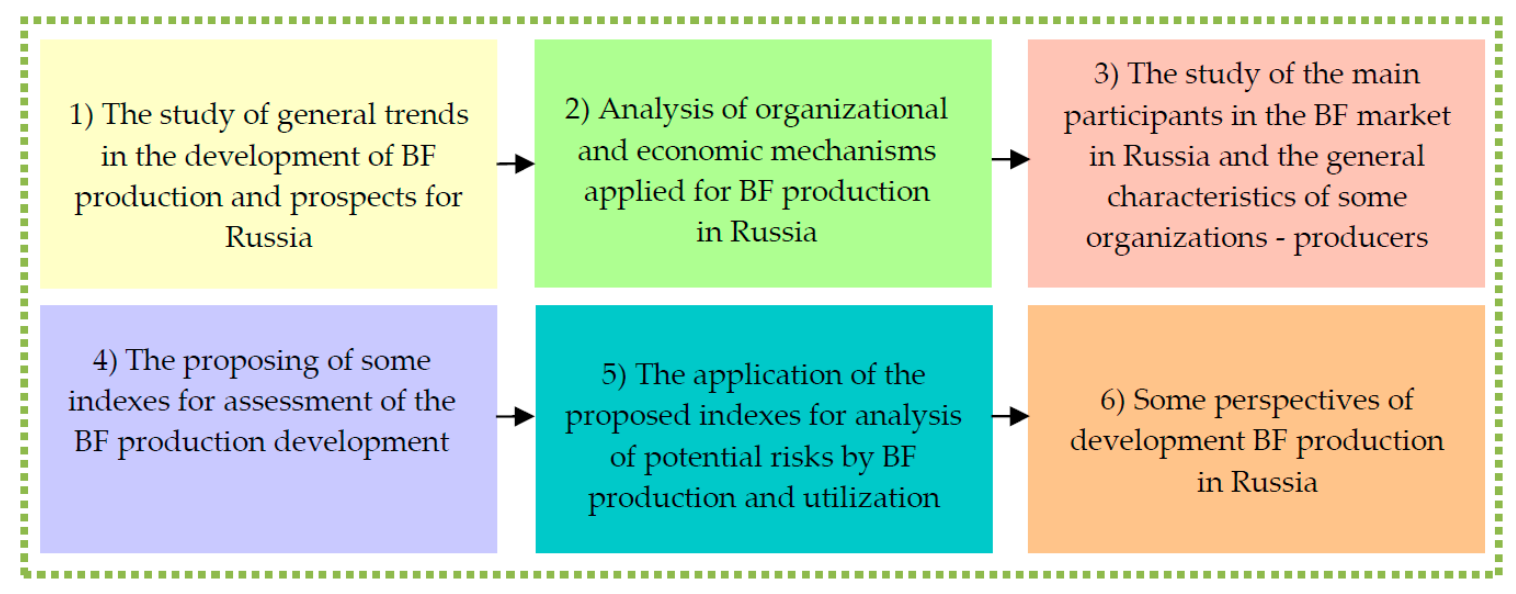

Figure 1. General study algorithm.

\section{General Trends of Biofuel Production Development and Some Prospectives for Russia (Research Background)}

Over several decades of development, some of the leading BF producers (USA, Brazil, Germany, China, India, etc.) [10] have covered a lot of ground in development and improvement of the used technologies. The first-generation technologies created in the beginning provided industrial manufacturing of the three main types of BF: Bioethanol, biodiesel, and biogas [30-32]. At this stage, starch-containing agriculture products were mainly used as raw materials. At the beginning of the 21st century, several new approaches and technologies were developed, which led to the expansion of BF production and appearing of the products named the second- and the third-generation BF.

For instance, biotechnologies allowing the transformation of carbohydrates not applied in the food industry but widely spread in plants (cellulose, hemicellulose, lignocellulose, xylogen, etc.) [33-35] has been created. In particular, the problem of efficient destruction of beta-glycosidic bonds which bond monomers in such biopolymers was solved. At the same time, wild-growing and cultivating oil plants were found. These plants began to serve as a more efficient raw material in the production of BF than various conventional plants (sunflower, soybean, etc.). As a result, this practice allowed the preservation of the purpose of traditional crops that are used in the food industry [35-37]. Pyrolysis started to be applied in BF production. In the course of this process, quick thermochemical decomposition of lignocellulose occurs at high temperatures and without oxygen $[38,39]$. The main product of it is levoglucosan, hexose anhydride (six-carbon monosaccharide) which is considered the most suitable substrate for further transformation into the second-generation BF [39]. Then the products of pyrolysis are exposed to, for instance, specific microbic conversion for production of ready-to-use $B F$, in particular, bioethanol [39].

Moreover, pyrolysis and other particular technologies allowed the use of some prokaryotic (cyanobacterial) and eukaryotic algae as raw materials for BF production [40-42]. Based on appropriate criteria, some authors categorize them as the third generation of technologies $[36,42]$.

Among the reasons for the use of cyanobacterial algal, it is noted that these microorganisms grow fast, and do not compete for agricultural lands and resources. At the same time, they can efficiently transform $\mathrm{CO}_{2}$ into different organic substances, including lipids and carbohydrates, in their cells [40]. With consideration of the high content of lipids and carbohydrates in biomass of Cyanobacteria and eukaryotic microalgae, technologies for the production of the third-generation BF were created and 
tested $[43,44]$. For instance, three main techniques are categorized as the third generation of bioethanol production technologies: (i) fermentation of processed biomass; (ii) dark fermentation of reserved carbohydrates and (iii) direct photofermentation from carbon dioxide to bioethanol using light energy. However, the conventional technologies of fermentation of biomass by using these microorganisms are still of great interest [43].

Considerable attention is also paid to the creation of technologies for the production of bio-oil and biodiesel from cyanobacterial algal [40,45]. Although the cost of algae bio-oil is still rather high (about $\$ 2 \mathrm{~L}^{-1}$ ), as compared to the costs of similar fossil fuel, the cost of such bio-oil may become competitive and occupy a significant market share in the following decades [46].

As can be seen from the given above information, among the characteristics of the three generations of $\mathrm{BF}$, an important place is given to the raw material principle, that is, the ability to process certain raw materials. Alas, this area is also undergoing evolution transformation. Recently there are reports surrounding the development of the new, fourth generation of technologies. Among the features of which is the application of technological principles involving the creation of specialized genetic engineered constructions, modifications of microorganism complexes, etc. [45,47]. The main steps of technological evolution in BF production are presented in Figure 2.

USED RAW MATERIALS

\begin{tabular}{|c|c|c|}
\hline G1 & $\begin{array}{l}\text { Starchy agricultural plants (sugar beet, wheat, corn) and oil } \\
\text { plants (rape etc.), palm oil }\end{array}$ & \multirow{4}{*}{$\begin{array}{l}\text { Thermochemical (pyrolysis, acid } \\
\text { hydrolysis, gasification, refining, } \\
\text { enrichment); biochemical (enzyme } \\
\text { conversion, distillation); microbiological } \\
\text { (using of microorganisms for anaerobic } \\
\text { fermentation) }\end{array}$} \\
\hline \multirow{2}{*}{ G2 } & $\begin{array}{c}\text { Cellulose containing biomass (wood, straw, grass, various } \\
\text { industrial and household wastes) }\end{array}$ & \\
\hline & Wild oil plants, saffron, jatropha, safflower & \\
\hline G3 & Micro- and macroalgae & \\
\hline G4 & $\begin{array}{l}\text { Cellulose and starch-containing biomass derived from } \\
\text { genetically modified microalgae and Cyanobacteria, as well as } \\
\text { some plants }\end{array}$ & $\begin{array}{l}\text { Genetic engineering technologies for the } \\
\text { formation of organisms with new metabolic } \\
\text { pathways and other useful properties }\end{array}$ \\
\hline
\end{tabular}

Figure 2. Scheme of the main steps made during the technological evolution in biofuel (BF) production. G1-first generation technologies [30-32,48-52]; G2-second generation technologies [34,39,49,52]; G3-third generation technologies [36,40-42,53-55]; G4-fourth generation technologies [45,47].

Optimization of the developed technologies has sufficiently accelerated the production processes and also led to an increase in the output of the final product and a decrease in its costs.

For example, a quite high yield of bioethanol has been achieved by the leading countries in conditions of industrial production (75-84\% of theoretically possible level and even approximating 95\%) [53]. At the same time, the applied technological solutions in the production of BF allowed obtaining an additional some valuable by-products (for instance, glycerin in biodiesel production) which are used in the pharmaceutical, cosmetic and chemical industry. As a result, the by-products began to contribute to the added value generated by the production of certain types of BF $[36,56]$.

One of the particular trends in contemporary bioenergy is the development of fuel pellet production technologies. Wood chips and other timber processing industry wastes are used as raw materials for this $[57,58]$. The trees growing both in a moderate climate (e.g., Pinus sylvestris) and in the tropics may be the source of such raw materials. The relevant products are in a significant demand on the world market due to the environmental component of consumer properties. Currently, the world community is striving to increase the share of REn production and application in the economy, mainly due to the perspective of the environmental safety provision. This striving is determined by the 
possibility of obtaining additional energy resources and the proven ecological effect from the reduction of $\mathrm{CO}_{2}$ emission $[54,59,60]$, efficient processing of steadily accumulating biological wastes [61,62] and non-demanded agricultural resources [63-65]. In many countries of the world, there are state plans for development and use of green energy based on REn [66-69] which have confirmed their efficiency. In this vein, it is interesting to note that the growth of electricity capacity with a cumulative result from 2014 to 2018 in global bioenergy, for example, amounted to 30\% [11] (Figure 3).

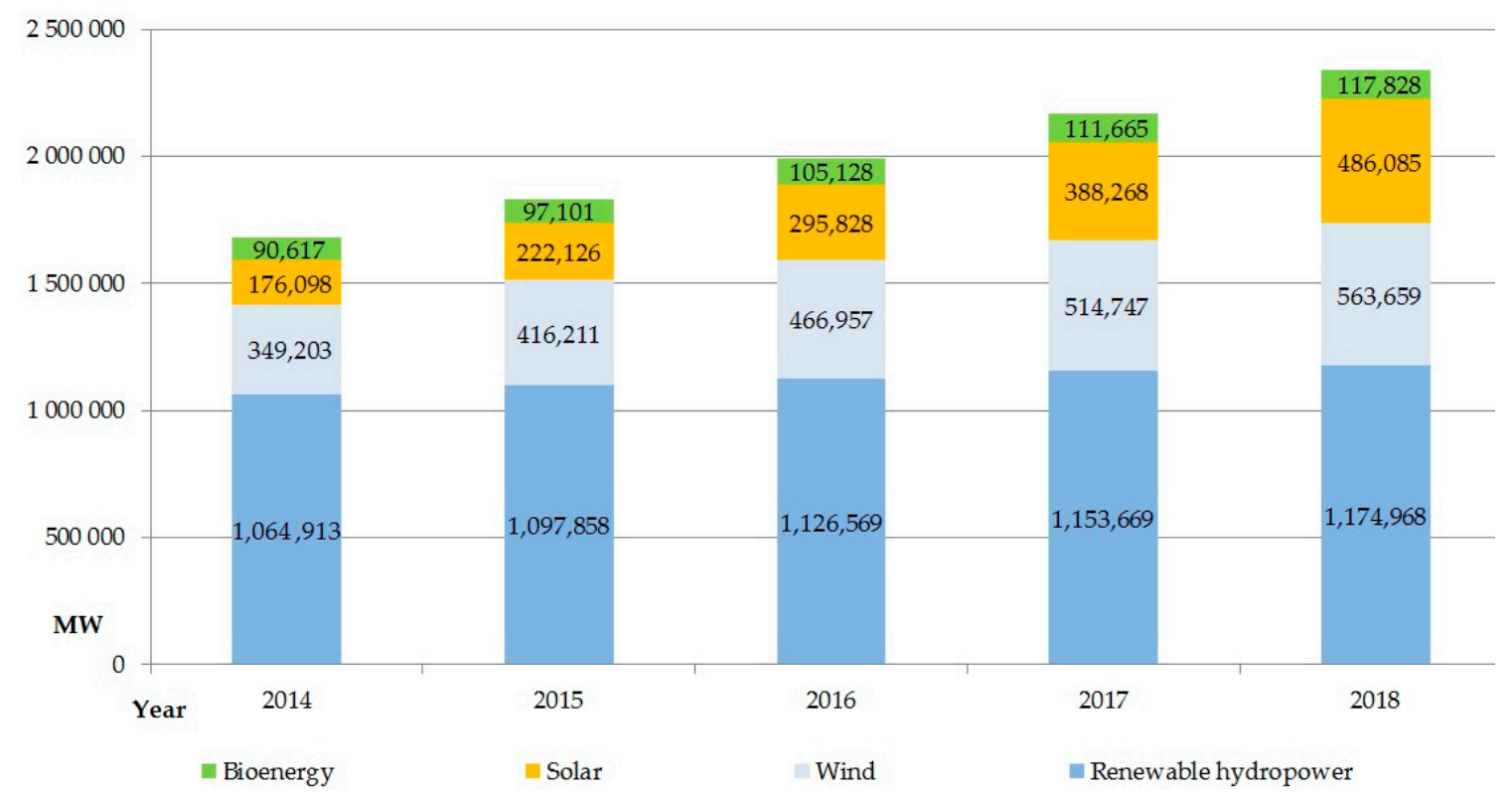

Figure 3. Dynamics of installed capacity of electricity production from renewable sources, megawatt (MW), (2014-2018) [11].

The significant economy indexes already reached in the course of implementation of such plans are confirmed by the materials of the European "Updated Bioeconomy Strategy" [70]. In particular, there are data on the annual growth of added value in the course of production of biochemicals (including BF), which has provided additional $€ 3.5$ billion of added value [70]. At the same time, it became known that from 2003 to 2018, world ethanol production increased by $230.5 \%$ [69]. Certainly, these results are caused by comprehensive organizational activities by the state and active institutions. Results of ongoing works on regulatory mechanisms improving, standardization of management processes, development, and unification of technological solutions in the area of BF are reflected in the different publications of many scientists from various countries, including Russia [71-77]. It is also worth noting that positive environmental effect from the application of $\mathrm{BF}$ is already being registered. For example, according to the available data [78], the $\mathrm{CO}_{2}$ emissions have reduced by 1.2 million tons since 2015 due to production of electricity using REn facilities. Moreover, a possible reduction of $\mathrm{CO}_{2}$ emissions may reach 7 million tons per annum due to application of green energy. Currently, there are opening opportunities for a comprehensive economic and environmental analysis from the results of technologies application used in the production of BF $[79,80]$. The suitable analysis will allow enhancing the evidential base in terms of positive characteristics of the application of BF and diffusion of innovations. As an illustration, the number of publications on economic results, technological features, and environmental consequences of industrial production of BF annually increased. In particular, there are different reports from Spain, Scandinavian countries, Thailand, etc. about the successful experience of BF production from agricultural wastes and timber biomass [81-83].

Due to this, the main direction of REn-based green energy development in Russia may be oriented on the growing opportunities for processing of non-demanded biological resources and various wastes into BF. Thanks to this, it is possible to expect an increase in production efficiency and qualitative 
change of environmental situation. Besides, several by-products are expected to be obtained [84-86], and these products can contribute to the added value in the production of BF [87].

\section{The Results of Analysis of Organisational and Economic Mechanisms Applied for Production of Biofuel in Russia: Status-Quo and Some Prospectives}

\subsection{Official Regulators and Participants of the Biofuel Market in Russia}

The energy sector of Russia based on conventional energy resources is the market barrier on the way of development of renewable energy. The existing production problems of REn facilities connection and high capital expenditures for construction of REn facilities [88] slow down the growth of potential utilization capacity of this type of energy.

The key roles in the economic life of Russia played by the state and other official regulators require special consideration within the analysis of organizational and economic mechanisms applied in BF production. Naturally, the Government and the specialized ministries are located on top of the management pyramid. Also, different programs and projects are developed and officially regulated by appropriate agencies, research, and educational institutions, technological platforms, as well as other organizations accumulating information on key stakeholders of the market. Such organizations may be considered a separate group which provides policy-making, development of significant state and regional programs as well as supervision of their implementation.

The group of the regulator organizations (i) actively cooperates with BF producers which are enterprises with different profiles, sizes, and forms of incorporation. BF producers may be considered as a separate group (ii) of the market participants. Another group of participants (iii) is de facto formed by different consumers. Some of them act as intermediate consumers, converting biofuels, for example, into electricity. Then, this electricity is transferred to end consumers. Finally, it seems appropriate to note various non-profit organizations, profile associations, specialized companies involved in market relations in the course of production and utilization of $\mathrm{BF}$, as a distinct group (iv). The general scheme of relations between the four groups of the BF market participants (organizations) is shown in Figure 4 . The analysis of information on these organizations will be given below.

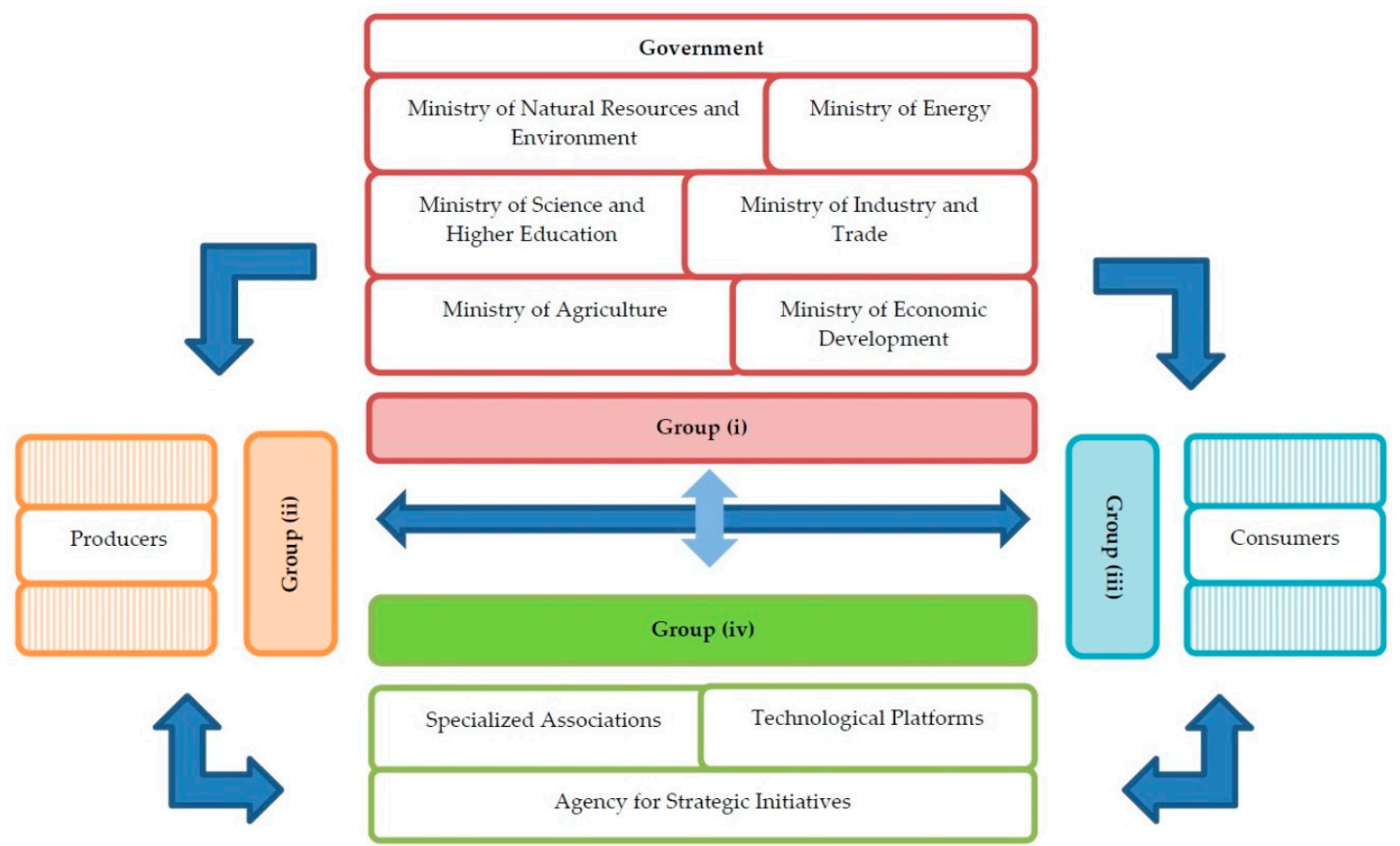

Figure 4. The general scheme of relations between the four groups of the BF market participants group (i) [89-92]; group (ii) [93,94]; group (iii) [94-96]; group (iv) [97-101]. 
It is worth noting that the Federal Law No. 35-FZ dated on March 26, 2003 "On Electric Energy" already provided different mechanisms of stimulation support of electric energy production by REn-based generating facilities with a capacity not exceeding $25 \mathrm{MW}$. For example, compensation was provided for the cost of technological connection to electrical networks [102]. The main conditions of the state regulation of the green energy production processes and utilization of renewable energy are applicable since 2009 following the Decree of the Government of the Russian Federation "The Energy Strategy of Development of Russia before 2030" [103].

One of the recent steps for implementation of the green energy development policy in Russia was introduction of amendments to the Federal Law No. 171-FZ dated on November 22, 1995 "On State Regulation of the Production and Distribution of Ethanol, Alcoholic and Alcohol-Containing Products and Restrictions on the Consumption (Drinking) of Alcoholic Products" [104,105]. As a result, some restrictions on bioethanol production were lifted. Also, the procedure of licensing of this type of activity was set out.

Moreover, over the previous 3-4 years, the Government of the Russian Federation and some profile ministries (the Ministry of Energy [89], the Ministry of Economic Development [90], the Ministry of Natural Resources and Environment [91], the Ministry of Industry and Trade [92]) compiled a number of statutory documents aiming at development of BF production in the country. In particular, the Government of the Russian Federation $[102,106]$ has provided for increasing the investment attractiveness of projects for the construction of REn-based generation facility. For this purpose, excessive requirements to the process of design, development, and operation of such generation facilities located in hard-to-reach and isolated areas were excluded. In addition, the Ministry of Energy of Russia prepared some of the measures for the systematization of management in energy and introduced the term "energy management" [107]. Thus, we can talk about the emergence of new opportunities for a system of energy management.

The group of regulator organizations (i) also takes new measures for improvement of the investment environment in the area of BF production. For instance, in 2018, The Ministry of Economic Development of Russia proposed the draft law "On Public Non-Financial Accounting" for public consideration and it currently undergoes expertise [108]. In particular, this document provides the establishment of conditions for the increase of transparency of organizations concerning environmental impact, awareness of the general public of the existing international social responsibility standards, and provision of sustainable development. The list of crucial indexes of the planned accounting will include such essential characteristics as determinants of the weight of pollutants emissions from stationary sources in atmosphere and the estimation of the contribution of energy resources produced employing of REn in the total volume of energy resource production. Moreover, the Government elaborated the plan [109] of reduction of the level of greenhouse gases emission down to $75 \%$ of the level of emissions in 1990 by 2020. This plan [109] also provides development of the relevant information base, forecasting the level of greenhouse gases emission for the period before 2020 and before 2030.

The conditions of BF productions may be significantly changed by the initiative of the Government of the Russian Federation for the introduction of amendments to the Federal Law "On Electric Energy" regarding the development of microgeneration [110]. The proposed changes will allow increasing the share of REn-based facilities with an installed capacity not exceeding $15 \mathrm{~kW}$ in Russian fuel and energy balance. The following measures are proposed for reaching of this target: (i) to provide an opportunity of sales of excessive produced energy in retail markets for default providers (not to consider such activity as business activity); (ii) to grant authorities for setting of aspects of commercial metering of the produced electric energy, determination of the procedure of payment and the procedure of microgeneration facilities utility connection, etc. to the Government of Russia; (iii) to establish an obligation of execution of an electric energy sale and purchase agreement between the default supplier and the microgeneration facility owner addressed to it and to define the mechanism of price formation for the electric energy purchased by it. 
Currently, the use of innovative technologies for the production of BF (I-IV generation) and systematic work on the spread of this type of energy resources have shown that on the scale of individual countries, thus the creating of prerequisites for sustainable economic development [111-114]. Consequently, in Russia, with the development of BF production without the use of food crops, similar results can be achieved. The elements of organizational and economic approaches aiming at reaching the said target presented in Figure 5.

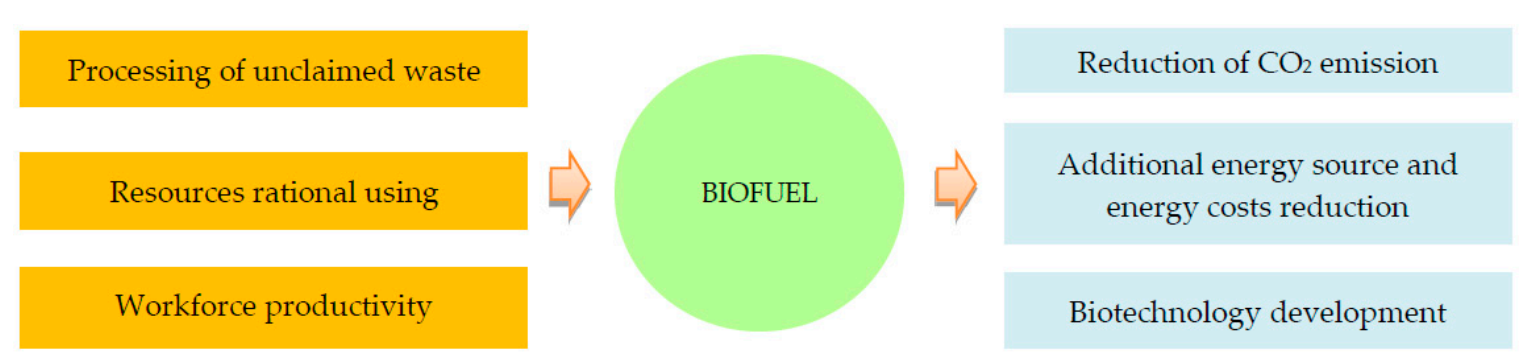

Figure 5. Scheme of organizational and economic approaches to use Biofuel production as a way to sustainable development in Russia regions [4,52,106,108,109].

The significance of waste processing problem in Russia has convincingly demonstrated the data contained in the documents of the Ministry of Natural Resources and Environment of the Russian Federation [91]. For instance, the State Environmental Protection Program states that the volume of waste processing will require to be increased by two times by 2020 and by ten times by 2025 [115]. According to the same Ministry, more than 60 million tons of solid household wastes are generated in Russia per annum. It corresponds to about $400 \mathrm{~kg}$ of residues per 1 person per year, and only about $7-8 \%$ of the collected wastes of this type are used in economic turnover [116].

According to the available estimations, currently, only $12 \%$ of the bioenergy potential of Russia is being used [117]. To combine the efforts of different ministries and agencies for the development of REn, including BF, is considered to appropriate the conduction, a comprehensive assessment of existing biological resources in dynamics. Special attention is paid to prospective of BF production and introduction of the relevant management mechanisms in the global energy and heat management system.

It is believed that the total amount of organic wastes in Russia can reach about 607,000 thousand tons per annum [3]. The available materials regarding the Federal districts of Russia $[3,12]$ allow characterizing the structure of gross potential of organic wastes which may be processed into BF (Figure 6). These and other indexes may be applied in the course of analysis of the potential reduction of $\mathrm{CO}_{2}$ emissions.

Taking into account the current situation, the Government of the Russian Federation approved the action plan "Development of Biotechnology and Gene Engineering" for 2018-2020 [118]. It specifies the establishment of regulatory, market, and technological conditions for bioenergy development in Russia with emphasis laid on the development of electric energy production.

In general, the efforts of the regulator organizations, lead to optimization of different producers and consumers of BF activity. For instance, the initiative mentioned above of the Government of the Russian Federation on the introduction of amendments to the Federal Law "On Electric Energy" [102] includes a provision that default suppliers are the organizations (including private companies) which conduct power supply. Such organizations shall enter into a power supply agreement and an electric energy (power) sale and purchase agreement with any consumers of electric energy addressing them. Persons acting on their behalf or behalf of another consumer of electrical power and to the benefit of the said consumer of electrical power may act as consumers [102]. As a result, a direct and useful tool for connecting microgeneration facilities to power grids will be. 


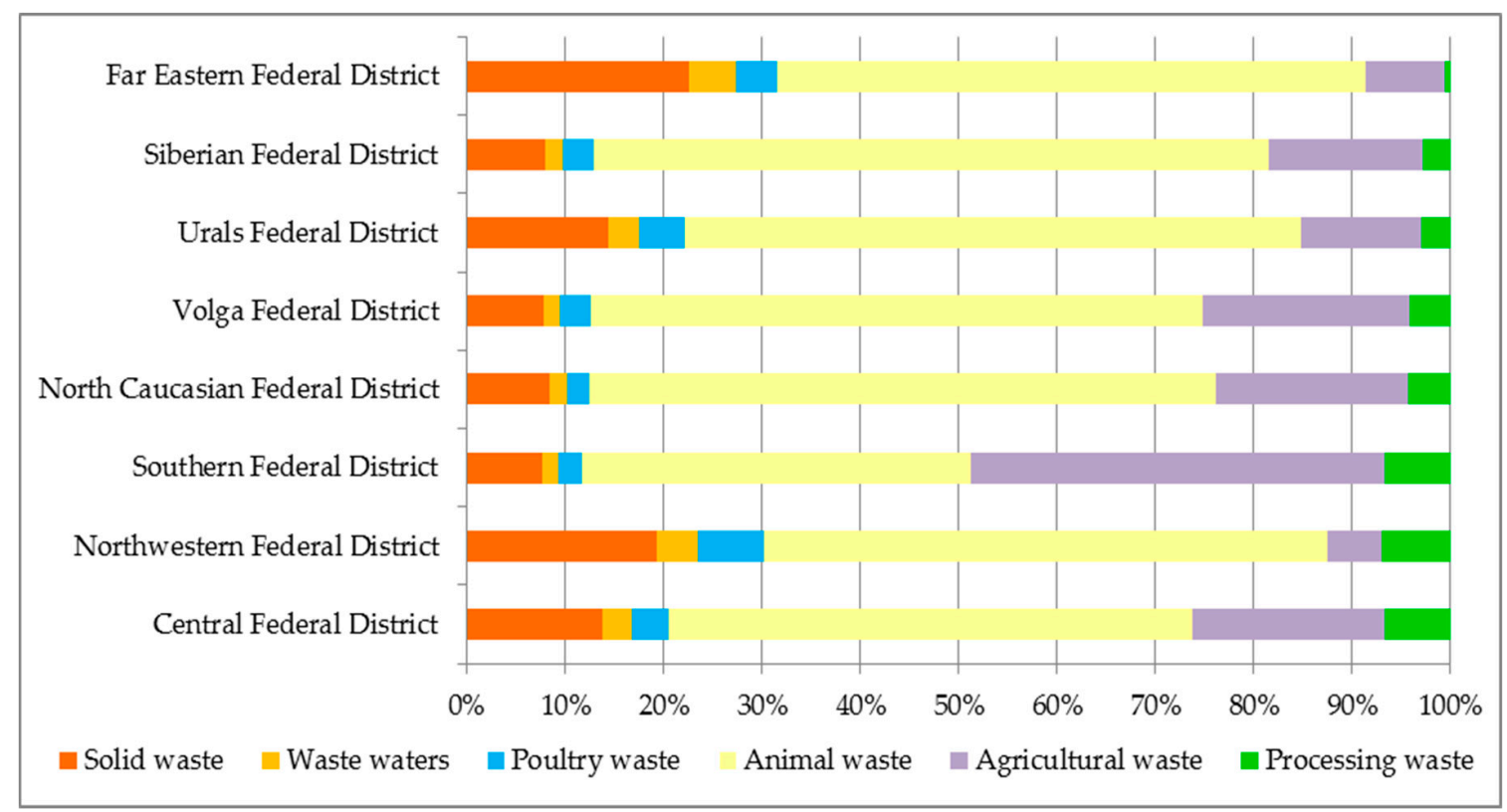

Figure 6. Structure of gross potential of organic wastes in Russian regions, thousand tons per year [3,12].

Some positive initiatives are contained in the draft Federal Law "On Introduction of Amendment to Article 217 of the Tax Code of the Russian Federation" [119]. In particular, it proposes to exempt the income of natural persons received from the sale of energy produced using the microgeneration facilities owned by such person from taxation.

In many cases, the state regulator organizations act as customers of works related to BF production in research and educational institutions. For instance, as part of the state contract, the Geographic Department of Moscow State University [120] and the Joint Institute for High Temperatures of the Russian Academy of Sciences [121] created the special geo-informational portal GIS RENEWABLE ENERGY SOURCES OF RUSSIA [3]. This web resource contains many essential materials on renewable energy in Russia, concerning new technologies and BF production facilities as well as other useful information. This portal will assist in the establishment of an efficient logistics and sales concept of BF utilization in Russia as well as investment planning.

The list of research institutions of the Russian Federation involved in studies of BF creation and utilization includes, in particular, Research Center of Biotechnology RAS [122], National Research Center "Kurchatov Institute" [123], Joint Institute for High Temperatures of the Russian Academy of Sciences [121], etc. Some educational institutions also participate in this work: Moscow State University [120], National University of Oil and Gas "Gubkin University" [124], National Research Nuclear University MEPhI (Moscow Engineering Physics Institute) [125], Moscow Polytechnic University [126]. Also, there are seven specialized departments in educational institutions providing education in the field of REn [78]. However, this is not sufficient for the intentions of the long-term development of this type of production. Nevertheless, the educational standard for bioenergy and biofuel production specialist has already been approved [127].

A functional role is also played by several technology platforms related to production of BF (Bioenergy [97] and Biotech2030 [98]) with their activities also aiming at "utilization of renewable sources of biomass for the purposes of rational and sustainable industrial production and energy provision with lowering of negative environmental impact" etc.

In addition, the Government of Russia established the Agency for Strategic Initiatives [128] to assist in social and professional mobility of young professionals and teams in business and social areas, including by supporting of socially relevant projects and initiatives [128]. To reach this target, the Agency supports the implementation of the national technological initiative [128], which comprises the development of nine markets, including EnergyNet [129]. EnergyNet aims at the creation of smart 
energy networks, but "development of REn is also included in the wide area of interest" [129]. In the meantime, the roadmap approved by the Government [130] specifies "provision of efficient and reliable energy supplies for isolated and hard-to-reach territories by 2020 using hybrid systems (the optimal combinations of technical solutions: Renewable sources of energy, diesel, gas, local types of fuel, innovative generation, accumulators, electric energy distribution systems, management systems)", including by lifting administrative barriers, among the results planned by June, 2020 .

Some non-profit organizations, e.g., Association "Nonprofit Partnership Council for Organizing Efficient System of Trading at Wholesale and Retail Electricity and Capacity Market" (Association "NP Market Council") are known too [131]. This organization certifies the generating facilities which utilize REn and maintains the register of issuance and revoking of certificates confirming the production volume of REn-based electric energy. Over the several years of its activity, the following facilities were included in the list of certified generating facilities utilizing organic raw materials (biomass, wastes): "Bely Ruchei" industrial mini-HES (Heating electrical station) (6 MW, Vologda region), "Luchki" biogas power plant and "Baitsury" biogas station (3.6 MW and 0.526 MW respectively, Belgorod region) and the "Novy Svet-Eko" solid waste landfill active degassing station with a landfill gas (LFG) power plant (2.4 MW, Leningrad region).

In the Russian BF market and the REn market in general, there is an additional but essential group (iv) composing by organizations with different forms of ownership. Their activities are oriented on arrangement and coordination of cooperation between producers and consumers of BF for the provision of rational and sustainable industrial production and energy supplies with lowering of negative environmental impact.

This group (iv) includes Joint-stock company «Trading System Administrator of Wholesale Electricity Market Transactions» (JSC “TSA") [132], a subsidiary of Association “NP Market Council” [131], which is empowered to conduct tenders and ensure settlements between producers and buyers of electricity. Between 2013 and 2018, JSC “TSA" has selected 229 investment projects of construction of REn-based generating facilities with installed capacity exceeding 5 gigawatt $(\mathrm{GW})$ for further support.

Different profile Associations play significant roles as cooperation coordinators. Among them, the Russian Biofuel Association [100], ENBIO Association [101], “Global Energy” Association for Development of International Energy Research and Projects [133] are especially active.

Establishment of Russia Renewable Energy Development Association (RREDA) [78] in 2019 was an essential event for REn development in Russia. Among the Association goals are assistance in the development of REn in Russia and member states of the Eurasian Economic Union, development of international cooperation, popularization of knowledge, increasing of skills in the field of REn, participation in the industry regulations development, etc.

Data about the most active innovative Russian enterprises producing BF and consumers of this type of energy resources will be reviewed in the following subsections with consideration of the regional aspect.

\subsection{Liquid Biofuel Producers}

The reserves of conventional energy resources available in Russia in conjunction with high capital expenditures in the production of liquid BF do not create conditions for proper development of that industry. Moreover, the legislation is still in transition and requires improvement.

Reprofiling of existing ethanol plants due to carving out of bioethanol from the law "On State Regulation of Production and Turnover of Ethanol" may become an impulse for the development of production of liquid BF [104,105]. For instance, the capacities of 17 ethanol plants in the Republic of North Ossetia-Alania which may be used for the production of bioethanol are unemployed, which is confirmed by the report of the Head of the Republic [134]. At the same time, the international standards, in particular, of fuel bioethanol, mixtures of biodiesel fuel, etc. are applicable in Russia [135-137]. Therefore, there are opportunities for production and using liquid BF in volumes sufficient for utilization as part of $5-10 \%$ mixture with gasoline [138-142]. Appearing of corresponding plan 
indicators may be expected to assist in the development of this type of activity and enhancement of environmental situation.

Development of appropriate biotechnological production may become another institutional breakthrough. For example, the Titan group [143], which is involved in petrochemical and agricultural production, is planning to start producing bioethanol of grain in the coming years [144].

At the same time, according to available data, the raw material supplies base of bioethanol production may be provided by agrarian regions of Russia by the processing of unclaimed agricultural products. On the example of certain regions of South of Russia, it is shown that the economic activity for the development of green energy and utilization of REn has begun as part of the state and regional programs and upon private initiative [52]. However, there are also significant untapped opportunities.

Some active enterprises capable of processing bioethanol into products with the price compared to that of the petrochemical plants production may be an exciting example promising for production and further utilization of liquid BF in Russia [113]. Such activity is already commenced by ETB Catalytic Technologies [145].

According to the basic forecast of IRENA, with target-oriented management, cumulative consumption of liquid BF in Russia may reach 200 petajoule (PJ) by 2030 [12]. Therefore, there is the reason to believe that in the future production of liquid BF will reach a decent level and will assist in the sustainable development of different regions of Russia. The questionnaire survey showed that at least eight Russian enterprises are planning to start producing liquid BF in the near future.

\subsection{Producers and Consumers of Solid Biofuel}

The conducted analysis showed that current production of solid BF in different regions of Russia is oriented on the following major products: Fuel peat, timber, wood chips, and fuel pellets. It is fuel pellets that are on the leading interest for different producers as they are demanded in the global market and successfully exported. For instance, according to Proskurina et al. [146], the Russian production of fuel pellets will keep its high potential provided this product is sufficiently demanded by EU countries $[95,96]$.

With consideration of the existing achievements, the Strategy of Development of the Russian Timber Complex before 2030 was updated in 2018 [147]. In the course of its implementation, it is planned to achieve significant effects of the measures for stimulation of production, export, and consumption of BF. In particular, the basic scenario implies that the export of pellets will reach 3912 thousand tons by 2030 with a gross potential production volume of 3968 thousand tons. As a comparison, this volume was equal to 1112 thousand tons in 2016, i.e., it is planned to be tripled within 15 years. In case of successful implementation of the updated strategy, the federal and regional budget revenues may reach 1.4 billion rubles per annum in 2030 [147].

The forecast by IRENA suggests that cumulative consumption of solid biofuel in Russia may be equal to 146 PJ by 2030 [12]. Currently, the main part of pellet producers (about $60 \%$ ) is located in the North-West of Russia, and about 30\% is located in the Central region [148]. The leading pellet producing and exporting regions of Russia are Leningrad, Arkhangelsk, Irkutsk regions, Khabarovsk, and Krasnoyarsk krais [149].

In the Leningrad region, the regional state information system (GIS "Energo Efektivnost") is introduced for maintaining of energy-saving and energy efficiency [150]. The leading enterprises of the region are Vyborg Forestry Development Corporation [93], Setnovo (Stora Enso) [151], etc.

According to available data, the annual consumption of BF in the Arkhangelsk region is about 1.2 billion TCE, the share of BF utilization in public energy service reached $42.8 \%$ in 2018 whereas the plan indicator is $44 \%$ [152]. The region government sets itself the task to expand the use of REn obtained from wood reserves, that will provide up to $30 \%$ of the energy supply potential [153]. In the Irkutsk region, it is planned to increase the production of wood pellets by 3000 tons in Biotoplivo-Irkutsk Limited Liability Company (LLC), capital expenditures for production capacities will be equal to 
123.9 million rubles [154]. In Krasnoyarsk Krai, BF is utilized in 41 boiler plants, and it is planned to produce $59 \%$ of heat energy [155] using this type of fuel.

Production of pellets is intensively developed in many regions of the North-Western Federal District, Siberia and the Far East with the attraction of important investments. For instance, it is reported on plans of construction of a wood torrefaction plant in the Novgorod region, the project volume of investment will be equal to about 14 million dollars [156]. When characterizing producers and consumers of solid BF in some regions of Russia, it is necessary to note a plant functioning in Altai Krai since 2015, which besides sunflower meal and protein concentrate, produces 12,000 tons of fuel pellets [144].

According to the questionnaire survey conducted, 52 Russian enterprises are already producing or plan to start creating solid BF in the nearest future.

\subsection{Producers and Consumers of Biogas}

The "Luchki" biogas power plant (BPP) owned by AltEnergo (Belgorod region, Luchki settlement) has been efficiently operating in the Russian market for more than seven years [94]. Currently, the "Luchki" BPP annually processes about 95 thousand tons of raw materials using different types of environmental pollutants as raw materials: Solid cattle-breeding wastes (pig and chicken excrements, non-used parts of bodies of livestock animals, etc.), crop production wastes and household wastes. A pig-breeding farm supplying the raw materials using a particular pipeline is located nearby. As a result, according to current estimates, from the time of launch to 2018, the "Luchki" BPP processed about 350 thousand tons of waste [157]. In other words, this BPP achieves a rather significant environmental effect.

The produced biogas is used for generation of electric energy. The capacity of the generating unit reaches 3.6 MW, which allows producing up to 29.3 million $\mathrm{kWh}$ per annum. In 2015, LLC "AltEnergo" connected the "Luchki" BPP to the electric network of Interregional Distribution Grid Company of Centre JSC, Belgorodenergo. As part of the stimulation of electrical energy production by REn-based generating facilities, 50\% of the capital expenditures for network connection were compensated by the state [102]. Consequently, the "Luchki" BPP currently acts both as a producer of biogas and intermediate consumer, whereas the end-users of the produced electric energy are residents of neighboring settlements.

The output of electric energy produced by the "Luchki" BPP has been growing over the last years. For instance, the "Luchki" BPP produced 1.5 million kWh of electricity more in the first half of 2019 than in the similar period of 2018 [94].

Alongside with electric energy, the "Luchki" BPP created about 27 thousand Gcal of heat energy and obtained 90 thousand tons of biofertilizers as a by-product, which was successfully marketed [94].

For about seven years, Regional Energy Company LLC which produces biogas in the "Baitsury" $\mathrm{BPP}$ and processes it into electric energy generating 0.5 MW, has been operating in Belgorod region [158].

It appears that the development of renewable energy in the Belgorod region was provided by taking a set of institutional measures [159]. In particular, some pilot projects were implemented in this field, the regional REn research center was established, and bioenergy specialists were trained in local educational institutions. Last but not least, the relevant production facilities were constructed. A smart grid was established on the basis of AltEnergo and support of certified generating facilities was provided.

Recently, the leadership of the Belgorod region has identified regional target indicators of the development of REn-based green energy before 2020 [160] and specified tax benefits and subsidizing of credit interest rates [161].

It is worth noting that the concept of development of small-scale distributed energy before 2025 is developed and approved in the Belgorod region [162]. According to this plan, the number of generating units capable of processing the agricultural wastes shall rise up to 100 by 2025 (capacity of $223.3 \mathrm{MW}$ ). Consequently, the conditions for the efficient disposal of organic wastes will be established, which shall lead to a reduction of human-induced impact on the environment. Moreover, it is planned to widen 
the energy infrastructure and production energy clusters in rural areas, which will allow increasing the sustainability of power supplies and will limit the growth of prices for heat and electric energy. It is expected that the planned measures will provide sustainable development of the region [162].

To some extent, the positive experience of biogas production in the Belgorod region influences the neighboring regions of the Central Federal District of Russia. For instance, attention to the energy production from renewable raw materials was reflected in the recent Decree of the Head of Tambov Region "On Approval of the Concept and Program of Electric Energy development in Tambov Region in 2019-2023" [163]. This document provides data on the feasibility of deploying BF production from agricultural wastes. For the implementation of this task, it plans to build mini biogas heating and power plants in the existing pig-breeding farms for the production of electric energy and disposal of plant biomass and livestock waste. The designed capacity of the planned facilities for the energy production from renewable raw materials will lead to the production of both heat energy (4 thousand Gcal) and electric energy ( 8.3 million $\mathrm{kW}$ ) and by-products in the form of organic fertilizers (14.3 thousand tons). Moreover, JSC "Biokhim" is assumed to be one of the key players [164].

The authorities of the Lipetsk region also plan to use REn-based technologies. According to the analytical data presented in the Decree of the administration of the Lipetsk region [165], investments in solar and wind energy are evaluated as being of little promise for this region. It is preferred to develop renewable energy based on the processing of agricultural waste and construct small hydropower plants. It is believed that the gross bioenergy potential of crop waste in the Lipetsk region is 1153.5 thousand TCE and livestock: 104.4 thousand TCE. This raw material can ensure the production of $529.29 \mathrm{MW}$ of energy and even lead to energy independence of the agricultural sector in this region.

According to the questionnaire survey conducted, fourteen Russian enterprises are already producing, or plan to start producing biogas in the near future.

\subsection{Prospects of Utilization of Algae and Wastewaters as Raw Material for Biofuel Production in Russia}

Reportedly, over the first two decades of the 21st century, the tracked climatic changes and growing impact of human-induced factors have led to, in particular, an increase of biomass of cyanobacterial algal. This biomass is considered as promising raw material for the production of BF $[40,166]$. Cyanobacteria is a large and rather heterogeneous group of prokaryotic organisms, some species of which are toxic. In some regions of the world, including in Russia, these limnetic, and marine microorganisms have begun to affect the environment significantly and even potentially threaten human health.

It is known that Cyanobacteria and some eukaryotic microalgae have complex photosynthetic systems. These systems allow using solar energy for the accumulation of various organic compounds which may be used for the production of both BF and a number of valuable by-products $[40,167,168]$. There are several reports on the creation of the third generation of BF production technologies which allow processing algae, including specifically cultivated ones, into BF [169-173]. At the same time, some authors pose the question of whether it is possible to use contemporary technologies of algae processing effectively for environmentally clean production of BF and cleaning of wastewater $[46,174]$. It is also noted that currently there are different problems which make it complicated to give a positive answer to this question without any reasonable doubt.

For instance, according to some authors, the industrial utilization of cyanobacterial algal is not economically sustainable due to the comparatively high cost of production of required biomass [175]. Although there is a broad spectrum of methods for manufacturing and accumulation of these microorganisms, including separation of cells from surrounding liquid, apparently, there is still no universal technology. According to Singh \& Patidar [175], the efficient technique for this purpose may be a combination of different methods matching the following six criteria: Provision of biomass quality, economic cost, the quantity of biomass, appropriate processing time, maintenance of species specificity and nontoxicity. Singh \& Patidar [175] pay special attention to the methods based on different methods of filtering and ultra filtering stressing that they demonstrate high efficiency and economic cost, do not require any chemical actions and allow using filtered water (water recycles). 
The significance of emerging opportunities of algae and wastewaters processing may be presented using the example of the Volga river basin, the largest river in the European part of Russia. In particular, the long-term research of Cyanobacteria in the river Volga and many other water reservoirs of the Volga basin showed that the content of different species of these organisms reached rather high values in summer. For example, it was shown that average quantity and biomass of Picocyanobacteria in Gorky and Cheboksary basins of the river Volga might range between $34-322 \times 10^{3}$ cells per mL and $38-455 \mathrm{mg} / \mathrm{mL}^{3}$ respectively in summer [176]. In addition, molecular genetics methods and immunoassay, the populations of toxic Cyanobacteria synthesizing hepatotoxin (microcystin), were discovered in Upper Volga reservoirs [177]. It was also noted that non-indigenous species of planktonic algae previously inhabiting other regions of Eurasia or even North America appear in Volga water [178].

One might think that the conditions of the Volga reservoirs with a slow flow of water and relatively shallow water contribute to the intensive growth of planktonic Cyanobacteria. As a result, there is a very negative phenomenon called "water bloom" [176,179]. These processes are also significantly affected by the so-called diffusive pollution of the Volga basin water objects. The anthropogenic sources of it shall be studied, and the effect of them shall be minimized to enhance the environmental situation in this vast region [180]. Cyanobacteria accumulate in wastewaters and water treatment plants, like excessive planktonic microorganisms, shall be disposed of and they may be utilized, in particular, for production of BF and some by-products.

It is believed that currently the environmental situation is rather tense in the Volga basin due to the anthropogenic pollution [180]. Due to excessive discharges of polluted water, in particular, the active development of Cyanobacteria occurs [181]. For solving of the existing problems, the Presidium of Presidential Council of the Russian Federation elaborated and approved the federal project "Preservation and Prevention of Pollution of the River Volga" in 2017 [180,182]. By this project, a set of measures shall be taken for reduction of the volume of discharge of polluted water in the river Volga basin by $80 \%$ before 2025. In the course of implementation of the project, it is planned to construct several engineering, sanitary-hygienic facilities. Also defined is a list of treatment facilities that must be built in 16 regions of the Russian Federation involved in the project.

The initiatives, which are comprised by this project, may facilitate the development of unique, economic opportunities for production of BF directly of algae, wastewater and organic raw materials, that may be produced during wastewater treatment by the algae-bacterial consortium [183].

By the reference data $[183,184]$, there are consortiums of eukaryotic and prokaryotic algae, which are capable to provide a high level of synthetic wastewaters treatment. There is the opinion that these consortiums be able to eliminate up to $96 \%$ of chemical oxygen demand (COD) $[183,184]$.

The use of technology with the participation of such consortia of microorganisms seems to be quite promising given the volume of polluted wastewaters discharged by the constituent entities of the Russian Federation in the river Volga. It is estimated this amount could reach up to 3175 thousand $\mathrm{km}^{3}$ per annum [184].

Some propositions for determination of growing points for the production of BF in the Volga river basin are justified by the conducted studies and technical solutions related to the processing of Cyanobacteria into BF [184-187].

Thus, the orientation on the utilization of Cyanobacteria and eukaryotic algae in conjunction with the introduction of the third-generation BF production technologies is rather promising at least for some regions of Russia.

In conclusion, the analysis of the Status-Quo of BF production in Russia show that the creation of $\mathrm{BF}$ is performed with a relatively low level of subsidizing and at certain market limitations. Given this, the efforts aiming at the processing of different wastes and non-demanded raw materials seem to be promising. As a result, a significant economic effect which will allow for making a big step towards "establishment of the renewable energy sector" [129] is possible.

Apart from distinct environmental, social and economic advantages, according to some authors, production of BF may open a door for the transition of economy from the linear model to the closed 
cycle model or "circular economy" [188-192]. It is believed that transition to the circular economy is the most efficient method to provide sustainable development.

Hence, ongoing with the taken measures, it is necessary to assess the reached effects and possible risks in dynamics. Solving of such problems requires the formation of assessment, measurement instruments [189], and the determination of application conditions.

\subsection{Six Indexes for Assessment of the Biofuel Production Development}

The conducted analysis of organizational and economic mechanisms applied for production of BF in Russia and the obtained data on several producers allowed for proposing six individual indexes to the BF production development assessment. The proposed set of assessment tools is intended for use in the BF production management system in Russia.

First, at least for Russia, the level of raw material reserves may be one of the important indexes. Index assessment is proposed to be carried using the $\mathrm{k}(\mathrm{M})$ ratio:

$$
\mathrm{k}(\mathrm{M})=\mathrm{M}_{\mathrm{BF}} / \mathrm{M}_{\mathrm{n}}
$$

where $\mathrm{M}_{\mathrm{BF}}$ is the amount of available raw materials for $\mathrm{BF}$ production, $\mathrm{M}_{\mathrm{n}}$ is the number of raw materials required for the continuous production of $\mathrm{BF}$.

It is expected that calculation of the index (1) will allow systematizing the information about available raw materials, their types, territorial belonging and major technical and economic characteristics as well as on opportunities to use the existing reserves.

Secondly, the availability of BF for end consumers may be of significant importance. This characteristic may be assessed employing the index (2) represented by $\mathrm{BF}$ consumption ratio $\mathrm{k}(\mathrm{CON})$. For the corresponding calculation, it is necessary to define the share of energy consumption, produced by $\mathrm{BF}$, in the total energy consumption:

$$
\mathrm{k}(\mathrm{CON})=\mathrm{CON}_{\mathrm{BF}} / \mathrm{CON}_{\mathrm{t}}
$$

where $\mathrm{CON}_{\mathrm{BF}}$ is a volume of consumed electricity (in MW) or consumed heat energy (in gigajoule (GJ)) produced from $\mathrm{BF}, \mathrm{CON}_{\mathrm{t}}$ is the total consumption of electric or heat energy (in MW or GJ, respectively).

One might propose that determination of the index (2) in dynamics will allow for combining the data on BF sales, the territorial potential of use, technological connection to electric networks, and opportunities of interregional distribution.

It is suggested that, based on results of the index (2) analysis, opportunities for taking different measures aiming at the formation of the sustainable target market will appear [193].

Another one means of assessment may be monitoring of tariffs on energy resources produced from BF. For this purpose, it is proposed to compare the cost of a unit of energy produced from BF with conventional analog by calculating the cost ratio $\mathrm{k}(\mathrm{V})$ :

$$
\mathrm{k}(\mathrm{V})=\mathrm{V}_{\mathrm{BF}} / \mathrm{V},
$$

where $\mathrm{V}_{\mathrm{BF}}$ is the cost of a unit of energy produced from $\mathrm{BF}, \mathrm{V}$ is the cost of a unit of energy produced by conventional sources.

It is evident that for the development of efficient production of BF in Russia, it is necessary to give preference to competitive technologies of raw material processing, as well as to lower the number of subsidies and other financial incentives.

The following proposed index (4) is intended for assessment of technical support of BF production. This problem may be solved using the technical support ratio $\mathrm{k}(\mathrm{F})$ :

$$
\mathrm{k}(\mathrm{F})=\mathrm{F}_{\mathrm{BF}} / \mathrm{F}_{\mathrm{t}}
$$


where $\mathrm{F}_{\mathrm{BF}}$ is the number of machinery and equipment for the production of $\mathrm{BF}, \mathrm{F}_{\mathrm{t}}$ is the total number of energy machinery and equipment. The index (4) will allow characterizing the increase of the number of machinery and equipment for the production of $\mathrm{BF}$ in dynamic.

At the stage of mass production and application of $\mathrm{BF}$, it will be important to assess how it may be influenced by changes in the levels of state subsidizing. Hence, the special index (5) using the subsidizing ratio $\mathrm{k}(\mathrm{G})$ for analysis is introduced:

$$
\mathrm{k}(\mathrm{G})=\mathrm{G}_{\mathrm{BF}} / \mathrm{G}_{\mathrm{t}}
$$

where $G_{B F}$ is the number of subsidies for the development of $B F, G_{t}$ is the amount of state subsidies for innovative activities.

Lastly, with consideration of the fact that the role of the workforce capacity of BF production will rise, it is necessary to conduct monitoring of specialists involved in this production. The corresponding index (6) may be obtained using the ratio: $\mathrm{k}(\mathrm{H})$, which reflects the number of employees with specialized education in the area of $\mathrm{BF}$ production.

$$
\mathrm{k}(\mathrm{H})=\mathrm{H}_{\mathrm{BF}} / \mathrm{H}_{\mathrm{t}}
$$

where $\mathrm{H}_{\mathrm{BF}}$ is the number of employees with specialized education in BF production, $\mathrm{H}_{\mathrm{t}}$ is the total number of employees.

Currently, the estimated number of employments in the BF production sector is 1.9 million, and Brazil is justly considered the leader in terms of the number of employees [13]. In terms of this data, Russia significantly lags behind the leading countries. It is evident that an increase in employees' qualifications in BF production will be associated with long-term expenditures in the sphere of education for Russia. Management of this index (6) will allow providing human resources for BF production over the long term.

The proposed indexes are intended for detection of different necessary measures, which will be planned for the long-term development of BF production. Using the proposed indexes, various measures aiming at the development of $\mathrm{BF}$ production possible to plan and to take. The appropriate management may be implemented by analyzing the dynamics of these indexes and the application of targeted transmission mechanisms.

In particular, the index (1) may be considered convenient for determination of the balance between the amounts of available raw materials and the amounts required for maintaining of continuous production of $B F$. In this case, if it turns out that $\mathrm{k}(\mathrm{M})<1$, one should expect the suspension of production, with $\mathrm{k}(\mathrm{M})>1$, overstocking is possible. Therefore, the significant (indicator) value of the index (1) is 1.0. For correction of the situation and maintenance of continuous BF production, measures for optimization of generating facilities deployment and raw material base may be taken. Moreover, it is possible to change the methods of transfer or products transportation with the consideration of the location of the end-user.

The results of BF accessibility for end consumers determination using the index (2) may be useful for arrangement of measures aiming at the increase of the consumption ratio $\mathrm{k}(\mathrm{CON})$. The proposed significant (indicator) value of the index (2) is 0.05 . This value is based on an estimated share of BF consumption in the total amount of energy resources in Russia $[4,12,78]$. Among the measures which may influence this index, it is recommended to use the mixture of gasoline with addition of $10 \%$ of liquid $\mathrm{BF}$, to enhance the indirect BF costs control mechanism ("green tariff"), to keep tax benefits due to lack of mineral extraction tax, to consider possibility of quota arrangement of BF consumption. Also, the positive effect can provide the specialized information base containing data on the availability of raw materials for BF production, location of producers, licensors of technological solutions and possible consumers of BF in the territory of Russia.

Moreover, the measures aiming at achieving this goal may probably include different educational events for organizations producing and processing the crop products, timber industry enterprises as 
well as for concerned parties representing the private business. Participation of executive bodies and investors in such events is believed to be an essential condition for the achievement of expected effects.

The index (3) may be useful for taking measures aiming at the reduction of the cost of a unit of BF energy produced by BF. The possible ideal indicative value of this index is 1.0, i.e., equalizing of the cost of energy produced by renewable and conventional sources of energy. In this case, it is considered necessary to estimate the economic effect of $\mathrm{CO}_{2}$ emission prevention which is reached by using $\mathrm{BF}$ as compared to conventional hydrocarbon sources of energy.

The index (4) is intended for monitoring of increase by the number of machinery and equipment involved in the production by BF. The possible significant (indicator) value of this index is 0.05 as it reflects the share of equipment required in BF production in the total number of energy equipment in Russia with specific assumptions.

Development of this index may be stimulated by the provision of maximum equivalence of connection and introduction of environmental requirements for processing of waste and unnecessary agricultural products in BF. At the same time, it is also necessary to define the enterprise's fixed assets threshold deterioration level and efficient ways of possible interaction with the centralized distribution network.

The use of this index may assist in the popularization of knowledge on available BF generation technologies and equipment with different capacity. For example, the relevant information on existing mini-plants will be useful for organizing of the BF production in hard-to-reach or rural areas.

The results of the application of the index (5), using the subsidizing coefficient, apparently will be useful for efficient cooperation between BF producers and the regulator organizations. In case of positive economic effect and increase of the number of power supply agreements, it is proposed to balance the number of state subsidies and to consider the base trend of this type of investment the downtrend with use of the subsidizing ratio $\mathrm{k}(\mathrm{G})$. It appears that assessment of the significant (indicator) value of the index (5) is not possible so far.

The index (6) applying the $\mathrm{k}(\mathrm{H})$ ratio is intended for monitoring of specialists involved in $\mathrm{BF}$ production and may significantly influence the processes of training of such specialists. For instance, the obtained data on necessity of additional high-skilled specialists involvement in production of BF or on their retraining with consideration of new technologies and equipment will stimulate a set of measures, in particular, those aiming at updating of existing educational standards, modernization of educational programs and establishment of other conditions for additional BF-related education. The opportunity of scientific and educational support employing association of industrial enterprises with regional scientific and educational centers or specialized consulting facilities may play an essential role. It will become possible to define the significant (indicator) value of the index (6) as far as similar experience is accumulated.

Naturally, alongside the target measures causing influence on the process of creation and application of $\mathrm{BF}$, it is essential to assess possible risks which may cause a negative impact on the development of BF production.

\subsection{Application of the Proposed Indexes for Analysis of Potential Risks of Biofuel Production and Utilisation in Russia}

The assessment of risks faced by companies producing BF in different countries of the world is an essential component for rational decision-making [24-26]. Respectively, it appeared to be necessary to analyze the above-listed indexes for a description of potential risks which may arise in this sphere of activity in Russia. The risks were categorized and grouped according to the assumption that the state currently provides public assistance to this sector of the economy, and the political risks are minimal.

To define attitudes towards specific types of risk, the value of possible losses $\left(\mathrm{P}_{\mathrm{q}}\right)$ and possibility of arising (I) were estimated by reflecting the risk rank $\left(I_{r}\right)$ as the product of these values: $I_{r}=P_{q} \times I$. Risks ranging by degree and level of impact was undertaken by the E. Kulikova's method of determining the 
probability of risks [27]. The achieved results with the specification of opportunities to manage these risks are presented in Table 1.

Table 1. Assessment of potential risks of biofuel production in Russia.

\begin{tabular}{|c|c|c|c|c|c|c|}
\hline \multirow[b]{2}{*}{ № } & \multirow[b]{2}{*}{ Risks } & \multirow[b]{2}{*}{$\mathbf{P}_{\mathbf{q}}{ }^{1}$} & \multirow[b]{2}{*}{$\mathrm{I}^{2}$} & \multirow[b]{2}{*}{$\mathbf{I}_{\mathbf{r}}{ }^{3}$} & \multicolumn{2}{|c|}{ Addiction } \\
\hline & & & & & $\begin{array}{l}\text { Influence } \\
\text { Degree }\end{array}$ & $\begin{array}{l}\text { Influence } \\
\text { Level }\end{array}$ \\
\hline & operational, resource & & & & & \\
\hline 1 & Variable raw material supplies & 2 & 4 & 8 & Minor & Reasonable \\
\hline 2 & $\begin{array}{c}\text { Narrow range of raw material application } \\
\text { using existing equipment } \\
\text { distributive }\end{array}$ & 4 & 3 & 12 & Significant & Intolerable \\
\hline 3 & Market stagnation & 3 & 3 & 9 & Moderate & Reasonable \\
\hline 4 & $\begin{array}{c}\text { Lack of relevant target market, } \\
\text { insufficient supply, low volumes of sales } \\
\text { and distribution } \\
\text { financial }\end{array}$ & 2 & 5 & 10 & Moderate & Reasonable \\
\hline 5 & $\begin{array}{c}\text { High expenditures for popularization } \\
\text { events }\end{array}$ & 2 & 1 & 2 & Ignorable & Acceptable \\
\hline 6 & Growth of the energy unit cost & 4 & 3 & 12 & Significant & Intolerable \\
\hline 7 & Low efficiency of state subsidies & 2 & 5 & 10 & Moderate & Reasonable \\
\hline 8 & $\begin{array}{l}\text { Low efficiency of investments } \\
\text { human resource }\end{array}$ & 2 & 5 & 10 & Moderate & Reasonable \\
\hline 9 & $\begin{array}{l}\text { Insufficient human resources and low } \\
\text { level of trained human resources }\end{array}$ & 5 & 3 & 15 & Significant & Intolerable \\
\hline 10 & $\begin{array}{l}\text { Low quality of educational programs of } \\
\text { main and additional education }\end{array}$ & 3 & 3 & 9 & Moderate & Reasonable \\
\hline
\end{tabular}

The several application of the presented indexes for analysis of corresponding risks is presented below. For maintenance of positive dynamics of the index (1), it is necessary to determine the following risks: (i) variability of raw material suppliers; (ii) narrow range of raw material application by a specific enterprise using existing equipment. For index (2) with ratio $\mathrm{k}(\mathrm{CON})$, the risks may be caused by market stagnation and high expenditures for popularisation events.

The growth of the cost of an energy unit may be identified as the risk for index (3). The risks for the index (4) are the following: Lack of sales and distribution corresponding to production level, insufficient supply, low sales, and distribution.

Despite the fact that the significant (indicator) value of the index (5) and (6) currently appear to be impossible to be determined, studying of their changes over time and in conjunction with different other data on the state of BF production may become the basis for additional classification of some risks. For instance, based on the results of such studies of the index (5), it appears to be possible to note the risks caused by the low efficiency of state subsidies and low efficiency of investments. In turn, accumulation of information on human resources and the existing qualification level of available human resources which is reflected by the index (6) in dynamics, may become a basis for determination of relevant risks. With consideration of these reasons, some potential risks associated with the application of indexes (5) and (6) are also included in Table 1.

The materials accumulated in Table 1 allowed for proposing some methods for potential risk management of BF production in Russia (Table 2). Representation and grouping of these methods correspond to the order in Table 1. 
Table 2. Methods of risk management of biofuel production in Russia.

\begin{tabular}{|c|c|}
\hline № & Methods of Risk Management of Biofuel Production in Russia \\
\hline 1 & $\begin{array}{c}\text { Allocation of production in accordance with the accessibility of the raw material base } \\
\text { Obtainment of authentic information on suppliers } \\
\text { Entering into supply agreements with several suppliers } \\
\text { Planning of the required amount of raw materials for the provision of the supply system (when } \\
\text { raw materials are supplied using own production) } \\
\text { Insurance (of contractual obligations or own production of raw materials) } \\
\text { Selection of reserve suppliers and opportunities for supplies of alternative raw materials }\end{array}$ \\
\hline 2 & $\begin{array}{l}\text { Creation of production associations } \\
\text { Enhancement of production capabilities for the utilized types of raw materials }\end{array}$ \\
\hline 3 & $\begin{array}{l}\text { Stimulation of work performance by state mechanisms } \\
\text { Support of innovative, science, technical potential }\end{array}$ \\
\hline 4 & Monitoring of cost characteristics of products \\
\hline 5 & $\begin{array}{l}\text { State control of market barriers lifting } \\
\text { Establishment of a uniform informational source with free access for end consumers }\end{array}$ \\
\hline 6 & $\begin{array}{l}\text { Reduction of costs of energy production } \\
\text { State regulation of price-formation }\end{array}$ \\
\hline 7 & Reduction of expenditures per unit of product \\
\hline 8 & Increase of production output \\
\hline 9 & $\begin{array}{c}\text { Formation of human resource reserve by creating training programs for specialists with higher } \\
\text { and secondary education for the provision of all production systems } \\
\text { Optimization of personnel work depending on the level of employee efficiency } \\
\text { Supervision of the structure and amount of salaries } \\
\text { Compliance of the salary level of BF production enterprises active in a region with at least } \\
\text { average regional salary } \\
\text { Determination of incentive payments in the payroll fund for timely staff motivation }\end{array}$ \\
\hline 10 & $\begin{array}{l}\text { Involvement of representatives of technological platforms acting in the area of energy, scientific } \\
\text { organizations conducting fundamental and applied studies, producers of BF and BF-production } \\
\text { equipment, educational institutions and other concerned parties in formation and } \\
\text { implementation of educational programs } \\
\text { State approval of the educational programs and their constant improvement depending on the } \\
\text { necessity of practical implementation of technological solutions } \\
\text { Increase of qualification of enterprises' personnel using their own capital and the federal budget }\end{array}$ \\
\hline
\end{tabular}

\section{Discussion}

The gathered materials on the state and perspectives of development of renewable energy in Russia confirm that positive growth of production of power using different types of BF may be expected in the near future. Figure 7 summarizes the results of the conducted analysis and forecasting of the electric energy production volume by certified REn-based facilities with consideration of the discovered risks.

The expected growing trends of production using biogas, biomass, including solid wastes, and landfill gas utilization are shown by dashed lines which are built based on the calculations performed using the tendency function and the least square method [131,194].

The presented calculations and some noted-above data show that significant growth of production may be provided, in particular, by fuel pellets demanded in the global market. Biogas production and landfill gas processing also demonstrate positive dynamics provided targeted management is performed. 


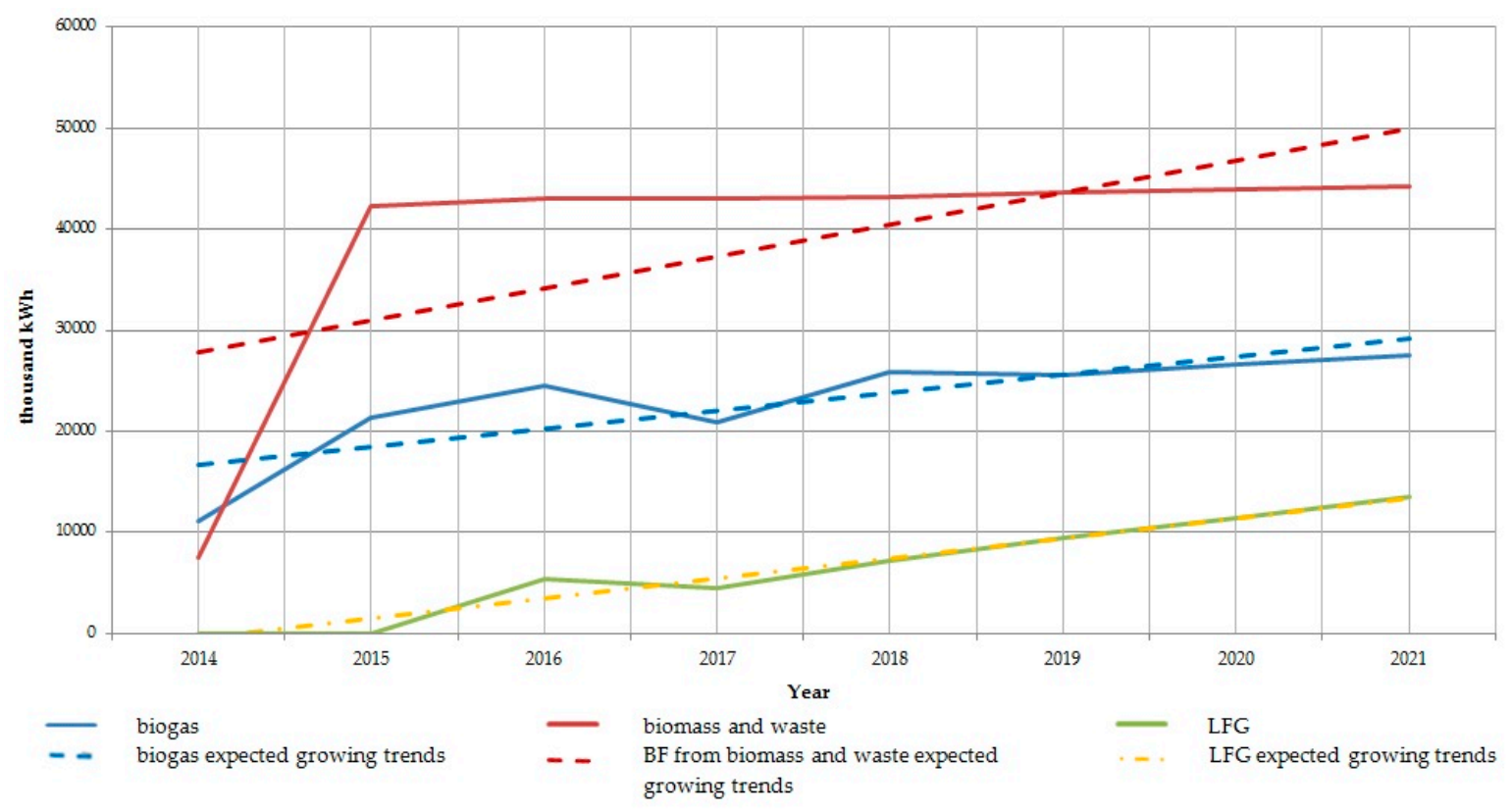

Figure 7. Forecasting of certificates confirmed electricity production by qualified renewable energy facilities (retail and wholesale markets), 2014-2021, thousand kWh [131,194].

Based on the existing data, it is possible to assume that institutional changes are required for the activation of liquid BF production. In addition, it appears to be necessary to grant the respective power to related ministries and agencies for the lifting of bureaucratic barriers. Moreover, it is essential to systematize the studies and available data on raw material reserves and technologies which may be applied in Russia. The positive impact may be caused by the resuming of existing but frozen ethanol plants operation. Conducting of full-scale works for fuel mixtures utilization may be of help too.

Generally, it seems that monitoring of the proposed indexes and other indicators influencing the production of BF may be useful for an increase in work efficiency. A significant role may be played by the creation of a specialized information base, which will provide all market participants with authentic information on dynamic changes in this area. Formulation of multiplicative (aggregate) coefficient which may be useful for reflection of relations between the discovered indexes with the assignment of weighting coefficients may be another organizational and economic mechanism contributing in the development of BF production in Russia $[195,196]$.

\section{Conclusions}

The progress in development and application of innovative technologies in BF production has become a significant factor contributing in the establishment of conditions for sustainable development of economy among the leading countries. Relevant environmental results have already been achieved: Effective recycling of various industrial, agricultural, and household wastes is carried out, greenhouse gas emissions in the environment are reduced, etc.

With this in mind, although in Russia the fuel and energy sector of the economy continues to be based mainly on conventional sources of energy, the production of biofuels is also beginning to deploy. In a relatively short time, the necessary legislative and regulatory system was largely created; dozens of enterprises that produce various types of biofuels appeared. Some types of produced BF (pellets) became exported goods.

The conducted analysis of organizational and economic mechanisms applied for BF production in Russia, and the obtained data on some producing organizations allowed proposing six distinct indexes for the assessment of such production performance. These indexes were used to describe potential risks, which may be faced in this sphere of activity in Russia. 
Therefore, the gathered materials allow us to suggest that BF production in Russia will develop and contribute to the sustainable development of a number of the country regions in the nearest future.

Moreover, taking into account the existing world experience, it can be assumed that in the coming years, the development aimed at improving biofuel production technologies will continue actively. In parallel, progress can be expected in managing the production and use of biofuels to achieve better economic results.

Acknowledgments: This research did not receive any specific grant from funding agencies in the public, commercial, or not for profit sectors.

Conflicts of Interest: The authors declare no conflict of interest.

\begin{tabular}{ll}
\multicolumn{2}{l}{ Abbreviation } \\
BF & Biofuel \\
REn & Renewable energy \\
TCE & Tons of coal equivalent \\
MW & Megawatt \\
HES & Heating electrical station \\
LFG & Landfill gas \\
JSC & Joint Stock Company \\
GW & Gigawatt \\
PJ & Petajoule \\
LLC & Limited Liability Company \\
BPP & Biogas power plant \\
GJ & Gigajoule \\
COD & Chemical oxygen demand
\end{tabular}

\section{References}

1. United Nations. Available online: https://www.un.org/sustainabledevelopment/ru/sustainable-developmentgoals/ (accessed on 20 June 2019).

2. Ars Technica. Available online: https://arstechnica.com/science/2019/01/renewables-led-by-wind-providedmore-power-than-coal-in-germany-in-2018/ (accessed on 20 June 2019).

3. GIS Renewable Energy Sources of Russia (GIS RESR). Available online: http://gisre.ru/tables\#bio (accessed on 9 August 2019).

4. Proskuryakova, L.N.; Ermolenko, G.V. The future of Russia's renewable energy sector: Trends, scenarios and policies. Renew. Energy 2019, 143, 1670-1686. [CrossRef]

5. Nuno, A.; John, F.A.S. How to ask sensitive questions in conservation: A review of specialized questioning techniques. Biol. Conserv. 2015, 189, 5-15. [CrossRef]

6. Balagué, C.; de Valck, K. Using Blogs to Solicit Consumer Feedback: The Role of Directive Questioning Versus No Questioning. J. Interact. Mark. 2013, 27, 62-73. [CrossRef]

7. Scoboria, A.; Memon, A.; Trang, H.; Frey, M. Improving responding to questioning using a brief retrieval training. J. Appl. Res. Mem. Cogn. 2013, 2, 210-215. [CrossRef]

8. Bondarchuk, M.M. Questioning as a method of identifying requirements for qualifications of workers in the textile industry. Educ. Sci. Russ. Abroad 2019, 51, 98-101.

9. Dolzhenko, Y.; Pozdnyakova, A. Online questionnaire survey as a modern and effective way of research. Transp. Bus. Russ. 2015, 1, 109-110.

10. International Renewable Energy Agency (IRENA). Available online: http://resourceirena.irena.org/gateway/ dashboard/?topic $=4 \&$ subTopic $=18$ (accessed on 19 July 2019).

11. International Renewable Energy Agency (IRENA). Available online: http://resourceirena.irena.org/gateway/ dashboard/?topic $=4 \&$ subTopic $=16$ (accessed on 19 July 2019).

12. International Renewable Energy Agency (IRENA). REMAP 2030. Available online: https://www.irena.org/ -/media/Files/IRENA/Agency/Publication/2017/Apr/IRENA_REmap_Russia_paper_2017.pdf (accessed on 19 July 2019). 
13. Renewable Energy Policy Network for the 21st Century (REN21). Renewables 2018. Global Status Report. Available online: http://www.ren21.net/gsr-2018/chapters/chapter_01/chapter_01/\#sub_4 (accessed on 17 June 2019).

14. Il'enkova, S.D.; Gohberg, L.M.; Kuznecov, V.I.; Yagudin, S.Y. Innovation Management; Moscow International Institute of Econometrics, Informatics, Finance and Law: Moscow, Russia, 2003.

15. Dutta, S.; Reynoso, R.E.; Bernard, A.L. The Global Innovation Index 2015: Effective Innovation Policies for Development. Available online: https://www.wipo.int/edocs/pubdocs/en/wipo_pub_gii_2015-chapter1.pdf (accessed on 23 July 2019).

16. Global Innovation Index 2018. Annex 2-Adjustments to the Global Innovation Index Framework and Year-on-Year Comparability of Results. Available online: https://www.wipo.int/edocs/pubdocs/en/wipo_ pub_gii_2018-annex2.pdf (accessed on 23 July 2019).

17. Crespo, N.F.; Crespo, C.F. Global innovation index: Moving beyond the absolute value of ranking with a fuzzy-set analysis. J. Bus. Res. 2016, 69, 5265-5271. [CrossRef]

18. National Innovation Report in Russia. Available online: https://www.rvc.ru/upload/iblock/c64/RVK_ innovation_2017.pdf (accessed on 23 July 2019).

19. Aleskerov, F.; Egorova, L.; Gokhberg, L.; Myachin, A.; Sagieva, G. Pattern Analysis in the Study of Science, Education and Innovative Activity in Russian Regions. Procedia Comput. Sci. 2013, 17, 687-694.

20. Miremadi, I.; Saboohi, Y.; Jacobsson, S. Assessing the performance of energy innovation systems: Towards an established set of indicators. Energy Res. Soc. Sci. 2018, 40, 159-176. [CrossRef]

21. Binz, C.; Truffer, B. Global Innovation Systems-A conceptual framework for innovation dynamics in transnational contexts. Res. Policy 2017, 46, 1284-1298. [CrossRef]

22. Janger, J.; Schubert, T.; Andries, P.; Rammer, C.; Hoskens, M. The EU 2020 innovation indicator: A step forward in measuring innovation outputs and outcomes? Res. Policy 2017, 46, 30-42. [CrossRef]

23. Dziallas, M.; Blind, K. Innovation indicators throughout the innovation process: An extensive literature analysis. Technovation 2019, 80-81, 3-29. [CrossRef]

24. Dong, J.; Xue, G.; Feng, T.; Liu, D. System Dynamics Modelling of Renewable Power Generation Investment Decisions under Risk. Int. J. Simul. Syst. Sci. Technol. 2016, 17, 1-10.

25. Pries, F.; Talebi, A.; Schillo, R.S.; Lemay, M.A. Risks affecting the biofuels industry: A US and Canadian company perspective. Energy Policy 2016, 97, 93-101. [CrossRef]

26. Abdullah, B.; Muhammad, S.A.F.S.; Shokravi, Z.; Ismail, S.; Kassim, K.A.; Mahmood, A.N.; Aziz, M.A. Fourth generation biofuel: A review on risks and mitigation strategies. Renew. Sustain. Energy Rev. 2019, 107, 37-50. [CrossRef]

27. Kulikova, E.E. Risk Management. Innovation Aspect; Berator-Publishing: Moscow, Russia, 2008.

28. Gokhberg, L.; Sokolov, A. Technology foresight in Russia in historical evolutionary perspective. Technol. Forecast. Soc. 2017, 119, 256-267. [CrossRef]

29. Hu, R.; Skea, J.; Hannon, M.J. Measuring the energy innovation process: An indicator framework and a case study of wind energy in China. Technol. Forecast. Soc. 2018, 127, 227-244. [CrossRef]

30. Guo, M.; Song, W.; Buhain, J. Bioenergy and biofuels: History, status, and perspective. Renew. Sustain. Energy Rev. 2015, 42, 712-725. [CrossRef]

31. Lopes, M.L.; Paulillo, S.C.; Godoy, A.; Cherubin, R.A.; Lorenzi, M.S.; Giometti, F.H.; Bernardino, C.D.; Amorim Neto, H.B.; Amorim, H.V. Ethanol production in Brazil: A bridge between science and industry. Braz. J. Microbiol. 2016, 47, 64-76. [CrossRef]

32. Saracevic, E.; Frühauf, S.; Miltner, A.; Karnpakdee, K.; Munk, B.; Lebuhn, M.; Wlcek, B.; Leber, J.; Lizasoain, J.; Friedl, A.; et al. Utilization of Food and Agricultural Residues for a Flexible Biogas Production: Process Stability and Effects on Needed Biogas Storage Capacities. Energies 2019, 12, 2678. [CrossRef]

33. Robak, K.; Balcerek, M. Review of Second Generation Bioethanol Production from Residual Biomass. Food Technol. Biotechnol. 2018, 56, 174-187. [CrossRef] [PubMed]

34. Castro, R.C.A.; Ferreira, I.S.; Roberto, I.C.; Mussatto, S.I. Isolation and physicochemical characterization of different lignin streams generated during the second-generation ethanol production process. Int. J. Biol. Macromol. 2019, 129, 497-510. [CrossRef] [PubMed]

35. Ruiz Olivares, A.; Carrillo-González, R.; del Carmen A. González-Chávez, M.; Soto Hernandez, R.M. Potential of castor bean (Ricinus communis L.) for phytoremediation of mine tailings and oil production. J. Environ. Manag. 2013, 114, 316-323. [CrossRef] [PubMed] 
36. Moncada, J.; Cardona, C.A.; Rincon, L.E. Design and analysis of a second and third generation biorefinery: The case of castorbean and microalgae. Bioresour. Technol. 2015, 198, 836-843. [CrossRef]

37. Titova, E.; Bondarchuk, N.; Romanova, E. Economic aspects of plants cultivation used as raw materials for biofuel production. Int. Agric. J. 2017, 1, 54-61.

38. Miskolczi, N.; Buyong, F.; Angyal, A.; Williams, P.T.; Bartha, L. Two stages catalytic pyrolysis of refuse derived fuel: Production of biofuel via syncrude. Bioresour. Technol. 2010, 101, 8881-8890. [CrossRef]

39. Islam, Z.U.; Yu, Z.; Hassan, E.B.; Chang, D.; Zhang, H. Microbial conversion of pyrolytic products to biofuels: A novel and sustainable approach toward second-generation biofuels. J. Ind. Microbiol. Biotechnol. 2015, 42, 1557-1579. [CrossRef]

40. Sarsekeyeva, F.; Zayadan, B.K.; Usserbaeva, A.; Bedbenov, V.S.; Sinetova, M.A.; Los, D.A. Cyanofuels: Biofuels from Cyanobacteria. Reality and perspectives. Photosynth. Res. 2015, 125, 329-340. [CrossRef]

41. Chen, W.H.; Lin, B.J.; Huang, M.Y.; Chang, J.S. Thermochemical conversion of microalgal biomass into biofuels: A review. Bioresour. Technol. 2015, 184, 314-327. [CrossRef]

42. Wang, Y.; Ho, S.H.; Yen, H.W.; Nagarajan, D.; Ren, N.Q.; Li, S.; Hu, Z.; Lee, D.J.; Kondo, A.; Chang, J.S. Current advances on fermentative biobutanol production using third generation feedstock. Biotechnol. Adv. 2017, 35, 1049-1059. [CrossRef]

43. Lakatos, G.E.; Ranglova, K.; Manoel, J.C.; Grivalsky, T.; Kopecky, J.; Masojidek, J. Bioethanol production from microalgae polysaccharides. Folia Microbiol. (Praha) 2019, 1-18. [CrossRef] [PubMed]

44. Abo, B.O.; Odey, E.A.; Bakayoko, M.; Kalakodio, L. Microalgae to biofuels production: A review on cultivation, application and renewable energy. Rev. Environ. Health 2019, 34, 91-99. [CrossRef] [PubMed]

45. Farrokh, P.; Sheikhpour, M.; Kasaeian, A.; Asadi, H.; Bavandi, R. Cyanobacteria as an eco-friendly resource for biofuel production: A critical review. Biotechnol. Prog. 2019, 35, e2835. [CrossRef] [PubMed]

46. Vo Hoang Nhat, P.; Ngo, H.H.; Guo, W.S.; Chang, S.W.; Nguyen, D.D.; Nguyen, P.D.; Bui, X.T.; Zhang, X.B.; Guo, J.B. Can algae-based technologies be an affordable green process for biofuel production and wastewater remediation? Bioresour. Technol. 2018, 256, 491-501. [CrossRef]

47. McLeod, C.; Nerlich, B.; Mohr, A. Working with bacteria and putting bacteria to work: The biopolitics of synthetic biology for energy in the United Kingdom. Energy Res. Soc. Sci. 2017, 30, 35-42. [CrossRef]

48. Schlör, H.; Venghaus, S.; Märker, C.; Hake, J.F. Managing the resilience space of the German energy system-A vector analysis. J. Environ. Manag. 2018, 218, 527-539. [CrossRef]

49. Golberg, A.; Sack, M.; Teissie, J.; Pataro, G.; Pliquett, U.; Saulis, G.; Stefan, T.; Miklavcic, D.; Vorobiev, E.; Frey, W. Energy-efficient biomass processing with pulsed electric fields for bioeconomy and sustainable development. Biotechnol. Biofuels 2016, 9, 94. [CrossRef]

50. Leksin, V.N.; Porfiryev, B.N. Socio-Economic Priorities of Sustainable Development of Russian Arctic Macro-Region. Econ. Reg. 2017, 13, 985-1004. [CrossRef]

51. Kuzmenkova, V.D. Sustainable development of Russian regions. Proc. Vor. State Univ. Eng. Technol. 2016, 2, 257-261. [CrossRef]

52. Bondarchuk, N.V.; Titova, E.S. Renewable energy prospects as one of sustainable development direction in some South Russian regions. South Russ. Ecol. Dev. 2017, 4, 12-31. [CrossRef]

53. Mulko, L.; Rivarola, C.R.; Barbero, C.A.; Acevedo, D.F. Bioethanol production by reusable Saccharomyces cerevisiae immobilized in a macroporous monolithic hydrogel matrices. J. Biotechnol. 2016, 233, 56-65. [CrossRef] [PubMed]

54. Alalwan, H.A.; Alminshid, A.H.; Aljaafari, H.A.S. Promising evolution of biofuel generations. Subject review. Renew. Energy Focus 2019, 28, 127-139. [CrossRef]

55. Sikarwar, V.S.; Zhao, M.; Fennell, P.S.; Shah, N.; Anthony, E.J. Progress in biofuel production from gasification. Prog. Energy Combust. Sci. 2017, 61, 189-248. [CrossRef]

56. Laker, F.; Agaba, A.; Akatukunda, A.; Gazet, R.; Barasa, J.; Nanyonga, S.; Wendiro, D.; Wacoo, A.P. Utilization of Solid Waste as a Substrate for Production of Oil from Oleaginous Microorganisms. J. Lipids 2018, 2018, 1578720. [CrossRef] [PubMed]

57. Lu, X.; Withers, M.R.; Seifkar, N.; Field, R.P.; Barrett, S.R.; Herzog, H.J. Biomass logistics analysis for large scale biofuel production: Case study of loblolly pine and switchgrass. Bioresour. Technol. 2015, 183, 1-9. [CrossRef] [PubMed]

58. Purohit, P.; Chaturvedi, V. Biomass pellets for power generation in India: A techno-economic evaluation. Environ. Sci. Pollut. Res. Int. 2018, 25, 29614-29632. [CrossRef] 
59. Rafaj, P.; Kiesewetter, G.; Gul, T.; Schopp, W.; Cofala, J.; Klimont, Z.; Purohit, P.; Heyesa, C.; Amann, M.; Borken-Kleefeld, J.; et al. Outlook for clean air in the context of sustainable development goals. Glob. Environ. Chang. 2018, 53, 1-11. [CrossRef]

60. Lyng, K.-A.; Brekke, A. Environmental Life Cycle Assessment of Biogas as a Fuel for Transport Compared with Alternative Fuels. Energies 2019, 12, 532. [CrossRef]

61. Teigiserova, D.A.; Hamelin, L.; Thomsen, M. Review of high-value food waste and food residues biorefineries with focus on unavoidable wastes from processing. Resour. Conserv. Recycl. 2019, 149, 413-426. [CrossRef]

62. Benato, A.; Macor, A. Italian Biogas Plants: Trend, Subsidies, Cost, Biogas Composition and Engine Emissions. Energies 2019, 12, 979. [CrossRef]

63. He, K.; Zhang, J.; Zeng, Y. Knowledge domain and emerging trends of agricultural waste management in the field of social science: A scientometric review. Sci. Total Environ. 2019, 670, 236-244. [CrossRef] [PubMed]

64. Dai, Y.; Sun, Q.; Wang, W.; Lu, L.; Liu, M.; Li, J.; Yang, S.; Sun, Y.; Zhang, K.; Xu, J.; et al. Utilizations of agricultural waste as adsorbent for the removal of contaminants: A review. Chemosphere 2018, 211, 235-253. [CrossRef] [PubMed]

65. Enes, T.; Aranha, J.; Fonseca, T.; Lopes, D.; Alves, A.; Lousada, J. Thermal Properties of Residual Agroforestry Biomass of Northern Portugal. Energies 2019, 12, 1418. [CrossRef]

66. Yang, X.J.; Hu, H.; Tan, T.; Li, J. China's renewable energy goals by 2050. Environ. Dev. 2016, 20, 83-90. [CrossRef]

67. Liu, J. China's renewable energy law and policy: A critical review. Renew. Sustain. Energy Rev. 2019, 99, 212-219. [CrossRef]

68. Rueda-Bayona, J.G.; Guzmán, A.; Cabello Eras, J.J.; Silva-Casarín, R.; Bastidas-Arteaga, E.; Horrillo-Caraballo, J. Renewables energies in Colombia and the opportunity for the offshore wind technology. J. Clean. Prod. 2019, 220, 529-543. [CrossRef]

69. Bórawski, P.; Bełdycka-Bórawska, A.; Szymańska, E.J.; Jankowski, K.J.; Dubis, B.; Dunn, J.W. Development of renewable energy sources market and biofuels in The European Union. J. Clean. Prod. 2019, 228, 467-484. [CrossRef]

70. European Commission. A Sustainable Bioeconomy for Europe: Strengthening the Connection between Economy, Society and the Environment: Updated Bioeconomy Strategy. Available online: https://ec.europa. eu/research/bioeconomy/pdf/ec_bioeconomy_strategy_2018.pdf (accessed on 23 February 2019).

71. Baral, N. What socio-demographic characteristics predict knowledge of biofuels. Energy Policy 2018, 122, 369-376. [CrossRef]

72. Liu, B.; Shumway, C.R.; Yoder, J.K. Lifecycle economic analysis of biofuels: Accounting for economic substitution in policy assessment. Energy Econ. 2017, 67, 146-158. [CrossRef]

73. Nugroho, Y.K.; Zhu, L. Platforms planning and process optimization for biofuels supply chain. Renew. Energy 2019, 140, 563-579. [CrossRef]

74. Ratner, S.V.; Ratner, M.D. Developing Regional Environmental Management Models in Compliance with the Innovative Format of ISO 14001:2015. Dig. Financ. 2017, 22, 163-174. [CrossRef]

75. Chen, R.; Qin, Z.; Han, J.; Wang, M.; Taheripour, F.; Tyner, W.; O'Connor, D.; Duffield, J. Life cycle energy and greenhouse gas emission effects of biodiesel in the United States with induced land, use change impacts. Bioresour. Technol. 2018, 251, 249-258. [CrossRef] [PubMed]

76. Rybicka, J.; Tiwari, A.; Leeke, G.A. Technology readiness level assessment of composites recycling technologies. J. Clean. Prod. 2016, 112, 1001-1012. [CrossRef]

77. Esteves, E.M.M.; Herrera, A.M.N.; Peçanha Esteves, V.P.; Rosário Vaz Morgado, C. Life cycle assessment of manure biogas production: A review. J. Clean. Prod. 2019, 219, 411-423. [CrossRef]

78. Russia Renewable Energy Development Association. Available online: https://rreda.ru/bulletin (accessed on 8 August 2019).

79. Budzianowski, W.M.; Budzianowska, D.A. Economic analysis of biomethane and bioelectricity generation from biogas using different support schemes and plant configurations. Energy 2015, 88, 658-666. [CrossRef]

80. Budzianowski, W.M. A review of potential innovations for production, conditioning and utilization of biogas with multiple-criteria assessment. Renew. Sustain. Energy Rev. 2016, 54, 1148-1171. [CrossRef]

81. Ruiz, D.; San Miguel, G.; Corona, B.; Gaitero, A.; Domínguez, A. Environmental and economic analysis of power generation in a thermophilic biogas plant. Sci. Total Environ. 2018, 633, 1418-1428. [CrossRef] 
82. Mustapha, W.F.; Trømborg, E.; Bolkesjø, T.F. Forest-based biofuel production in the Nordic countries: Modelling of optimal allocation. For. Policy Econ. 2019, 103, 45-54. [CrossRef]

83. Nutongkaew, P.; Waewsak, J.; Riansut, W.; Kongruang, C.; Gagnon, Y. The potential of palm oil production as a pathway to energy security in Thailand. Sustain. Energy Technol. 2019, 35, 189-203. [CrossRef]

84. de Jong, S.; Hoefnagels, R.; Wetterlund, E.; Pettersson, K.; Faaij, A.; Junginger, M. Cost optimization of biofuel production-The impact of scale, integration, transport and supply chain configurations. Appl. Energy 2017, 195, 1055-1070. [CrossRef]

85. Brosowski, A.; Krause, T.; Mantau, U.; Mahro, B.; Noke, A.; Richter, F.; Raussen, T.; Bischof, R.; Hering, T.; Blanke, C.; et al. How to measure the impact of biogenic residues, wastes and by-products: Development of a national resource monitoring based on the example of Germany. Biomass Bioenergy 2019, 127, 105275. [CrossRef]

86. Tanzer, S.E.; Posada, J.; Geraedts, S.; Ramírez, A. Lignocellulosic marine biofuel: Technoeconomic and environmental assessment for production in Brazil and Sweden. J. Clean. Prod. 2019, 239, 117845. [CrossRef]

87. Matraeva, L.; Solodukha, P.; Erokhin, S.; Babenko, M. Improvement of Russian energy efficiency strategy within the framework of "green economy" concept (based on the analysis of experience of foreign countries). Energy Policy 2019, 125, 478-486. [CrossRef]

88. Popel, O.S. Renewable energy sources: The role and place in modern and promising energy. Russ. Chem. J. 2008, 6, 95-106.

89. Ministry of Energy of Russian Federation. Available online: https://minenergo.gov.ru/node/987 (accessed on 8 August 2019).

90. Ministry of Economic Development of the Russian Federation. Available online: http://economy.gov.ru/ minec/activity/sections (accessed on 8 August 2019).

91. Ministry of Natural Resources and Environment of the Russian Federation. Available online: http: //www.mnr.gov.ru/docs/ (accessed on 8 August 2019).

92. Ministry of Industry and Trade of the Russian Federation. Available online: http://minpromtorg.gov.ru/ projects/general/ (accessed on 8 August 2019).

93. Vyborg Forestry Development Corporation. Available online: http://vfdc.ru/ru (accessed on 17 August 2019).

94. LLC “AltEnergo". Biogas Station. Available online: http://altenergo.su/biogas/ (accessed on 21 June 2019).

95. Sun, L.; Niquidet, K. Elasticity of import demand for wood pellets by the European Union. For. Policy Econ. 2017, 81, 83-87. [CrossRef]

96. Pristupa, A.O.; Mol, A.P.J. Renewable energy in Russia: The take off in solid bioenergy? Renew. Sustain. Energy Rev. 2015, 50, 315-324. [CrossRef]

97. Technological Platform “Bioenergy". Available online: http://www.tp-bioenergy.ru/about/management/ (accessed on 25 July 2019).

98. Technological Platform “Bioindustry and Bioresources” (BioTech2030). Available online: http://biotech2030. ru/deyatelnost/ (accessed on 25 July 2019).

99. Agency for Strategic Initiatives. Available online: https://asi.ru/about_agency/ (accessed on 31 July 2019).

100. Russian Biofuel Association (RBA). Available online: http://www.biotoplivo.ru/o-nas/ (accessed on 25 July 2019).

101. ENBIO. Association of Biofuel Market Participants. Available online: http://enbio.ru/rubric/novosti (accessed on 25 July 2019).

102. Federal Law of Russian Federation No. 35-FZ of March 26, 2003 “On Electric Energy". Available online: http://www.consultant.ru/document/cons_doc_LAW_41502/(accessed on 16 August 2019).

103. Decree of the Russian Federation Government of November 13, 2009 No. 1715-r “On the Energy Strategy of Development of Russia before 2030". Available online: https:/www.garant.ru/products/ipo/prime/doc/96681/ (accessed on 11 June 2019).

104. Federal Law of Russian Federation No. 171-FZ of November 22, 1995 “On Amendments in the State Regulation of Production and Turnover of Ethyl Alcohol, Alcoholic and Alcohol-Containing Products and Restriction of Alcoholic Products Consumption". Available online: http://www.consultant.ru/document/ cons_doc_LAW_8368/ (accessed on 16 August 2019).

105. Federal Law of Russian Federation No. 448-FZ of November 28, 2018 “On State Regulation of Production and Turnover of Ethyl Alcohol, Alcoholic and Alcohol-containing Products and Restriction of Alcoholic Products Consumption". Available online: http://www.consultant.ru/document/cons_doc_LAW_312102/ (accessed on 16 August 2019). 
106. Decree of the Russian Federation Government No. 1145 of September 27, 2018 “On Amending of Certain Acts of the Government of the Russian Federation Regarding the Promotion of the Use of Renewable Energy Sources". Available online: http://www.consultant.ru/document/cons_doc_LAW_307870/(accessed on 1 June 2019).

107. Ministry of Energy of Russian Federation. News Report "Alexander Novak Report on the Development of Energy Efficiency and Energy Saving". Available online: https://minenergo.gov.ru/node/9591 (accessed on 8 August 2019).

108. Draft of the Decree of the Russian Federation Government "On Approval of the List of Key (Basic) Indicators of Public Non-Financial Accounting". Available online: http://www.consultant.ru/cons/cgi/online.cgi?req= doc;base=PNPA; $n=46279 \# 08990458648385347$ (accessed on 11 June 2019).

109. Decree of the Russian Federation Government of April 2, 2014 No. 504-r “On Approval of an Action Plan to Ensure by 2020 the Reduction of Greenhouse Gas Emissions to No More Than 75 Percent of the Volume of These Emissions in 1990". Available online: http://www.consultant.ru/document/cons_doc_LAW_161475/ (accessed on 11 June 2019).

110. Order of the Russian Federation Government of November 3, 2018 No. 2381-r "On Amendments to the Federal Law “On Electric Power" Regarding the Development of Micro-Generation". Available online: http://government.ru/activities/selection/301/34594/ (accessed on 11 June 2019).

111. Acheampong, M.; Ertem, F.C.; Kappler, B.; Neubauer, P. In pursuit of Sustainable Development Goal (SDG) number 7: Will biofuels be reliable? Renew. Sustain. Energy Rev. 2017, 75, 927-937. [CrossRef]

112. Tsita, K.G.; Kiartzis, S.J.; Ntavos, N.K.; Pilavachi, P.A. Next generation biofuels derived from thermal and chemical conversion of the Greek transport sector. Therm. Sci. Eng. Prog. 2019, 100387. [CrossRef]

113. Boboescu, I.Z.; Chemarin, F.; Beigbeder, J.-B.; de Vasconcelos, B.R.; Munirathinam, R.; Ghislain, T.; Lavoie, J.-M. Making next-generation biofuels and biocommodities a feasible reality. Curr. Opin. Green Sustain. Chem. 2019, 20, 25-32. [CrossRef]

114. Sun, C.H.; Fu, Q.; Liao, Q.; Xia, A.; Huang, Y.; Zhu, X.; Reungsang, A.; Chang, H.-X. Life-cycle assessment of biofuel production from microalgae via various bioenergy conversion systems. Energy 2019, 171, 1033-1045. [CrossRef]

115. Resolution of the Government of Russian Federation No. 326 of April 15, 2014 “On Approval of the State Environmental Protection Program for 2012-2020". Available online: http://www.consultant.ru/document/ cons_doc_LAW_162183/(accessed on 21 May 2019).

116. Order of the Ministry of Natural Resources and Ecology of the Russian Federation of August 14, 2013 No. 298 "On Approval of a Comprehensive Strategy for the Treatment of Solid Municipal (Household) Waste in the Russian Federation". Available online: https://www.garant.ru/products/ipo/prime/doc/70345114/ (accessed on 11 June 2019).

117. Namsaraev, Z.B.; Gotovtsev, P.M.; Komova, A.V.; Vasilov, R.G. Current status and potential of bioenergy in the Russian Federation. Renew. Sustain. Energy Rev. 2018, 81, 625-634. [CrossRef]

118. Decree of the Russian Federation Government No. 337-r of February 28, 2018 “On Approval of the Action Plan ("Road Map") “Development of Biotechnologies and Gene Engineering" for 2018-2020". Available online: http://www.garant.ru/products/ipo/prime/doc/71792682/ (accessed on 11 June 2019).

119. Federal Law Draft "On Amending Article 217 of the Tax Code of the Russian Federation". Available online: http://government.ru/activities/selection/302/37660/ (accessed on 21 July 2019).

120. Moscow State University. Available online: https:/www.msu.ru/science/sci-dir-1.html (accessed on 8 August 2019).

121. Joint Institute for High Temperatures of the Russian Academy of Sciences. Available online: https://jiht.ru/science/ (accessed on 8 August 2019).

122. The Federal Research Centre "Fundamentals of Biotechnology" of the Russian Academy of Sciences (Research Center of Biotechnology RAS). Available online: https://www.fbras.ru/napravleniya-nauchnyx-issledovanij/ nauchnaya-deyatelnost (accessed on 25 July 2019).

123. National Research Center "Kurchatov Institute". Available online: http://www.nrcki.ru/catalog/index.shtml? g_show=7732\&path=3977,7732 (accessed on 8 August 2019).

124. National University of Oil and Gas "Gubkin University". Available online: https:/gubkin.ru/faculty/ chemical_and_environmental/chairs_and_departments/general_and_inorganic_chemistry/ (accessed on 8 August 2019). 
125. University MEPhI (Moscow Engineering Physics Institute). Available online: https://mephi.ru/science/ osnovnye_nauchnye_napravleniya.php (accessed on 8 August 2019).

126. Moscow Polytechnic University. Available online: https://mospolytech.ru/index.php?id=7 (accessed on 8 August 2019).

127. Decree of Ministry of Labor and Social Protection of Russian Federation No. 1047n of December 21, 2015 “On Approval of the Professional Standard "Specialist in the Organization of Bioenergy and Biofuel Production". Available online: http://base.garant.ru/71312996/ (accessed on 14 June 2019).

128. Order of the Russian Federation Government of August 11, 2011 No. 1393-r "On the Establishment of an Autonomous Non-Profit Organization "Agency of Strategic Initiatives for Promoting New Projects". Available online: https://asi.ru/upload/medialibrary/3e7/1393-upd2.pdf (accessed on 15 June 2019).

129. EnergyNet. Available online: http://www.nti2035.ru/markets/energynet (accessed on 31 July 2019).

130. Decree of the Russian Federation Government No. 830-r of April 28, 2018 "On Approval of the Plan "Roadmap" to Legislation Improving and Administrative Barriers Removing to Ensure the Implementation of the National Technology Initiative “EnergyNet". Available online: http://government.ru/docs/32548/ (accessed on 31 May 2019).

131. Association "Nonprofit Partnership Council for Organizing Efficient System of Trading at Wholesale and Retail Electricity and Capacity Market" (Association "NP Market Council”). Available online: https: //www.np-sr.ru/ru/market/vie/index.htm (accessed on 14 June 2019).

132. Trading System Administrator of Wholesale Electricity Market Transactions (TSA). Available online: http: //www.atsenergo.ru/vie (accessed on 14 June 2019).

133. Global Energy. Association for the Development of International Research and Projects in the Field of Energy. Available online: https://globalenergyprize.org/ru/about-us/about-us (accessed on 25 July 2019).

134. Ministry of Economic Development of the Republic of North Ossetia-Alania. Available online: http: //economy.alania.gov.ru/news/278 (accessed on 14 June 2019).

135. Interstate Standard (GOST 33872-2016). Fuel Denatured Bioethanol; Standartinform: Moscow, Russia, 2017; Available online: http://docs.cntd.ru/document/1200145331 (accessed on 11 June 2019).

136. Interstate Standard (GOST 33131-2014). Mixtures of Biodiesel (B6-B20); Standartinform: Moscow, Russia, 2016; Available online: http://docs.cntd.ru/document/1200121053 (accessed on 11 June 2019).

137. Interstate Standard (GOST 33113-2014). B100 Basic Biodiesel Fuel and Biodiesel Mixtures; Standartinform: Moscow, Russia, 2016; Available online: http://docs.cntd.ru/document/1200121050 (accessed on 11 June 2019).

138. Ershov, M.A.; Grigoreva, E.V.; Habibullin, I.F.; Emelyanov, V.E.; Strekalina, D.M. Prospects of bioethanol fuels E30 and E85 application in Russia and technical requirements for their quality. Renew. Sustain. Energy Rev. 2016, 66, 228-232. [CrossRef]

139. Joseph, O.O.; Loto, C.A.; Joseph, O.O.; Dirisu, J.O. Comparative Assessment of the Degradation Behaviour of API 51 X65 And Micro-Alloyed Steels in E20 Simulated Fuel Ethanol Environment. Energy Procedia 2019, 157, 1320-1327. [CrossRef]

140. Johansen, L.C.R.; Hemdal, S.; Denbratt, I. Comparison of E10 and E85 spark ignited stratified combustion and soot formation. Fuel 2017, 205, 11-23. [CrossRef]

141. Tao, J.; Yu, S.; Wu, T. Review of China's bioethanol development and a case study of fuel supply, demand and distribution of bioethanol expansion by national application of E10. Biomass Bioenergy 2011, 35, 3810-3829. [CrossRef]

142. Yusri, I.M.; Mamat, R.; Najafi, G.; Razman, A.; Awad, I.O.; Azmi, W.H.; Ishak, W.F.W.; Shaiful, A.I.M. Alcohol based automotive fuels from first four alcohol family in compression and spark ignition engine: A review on engine performance and exhaust emissions. Renew. Sustain. Energy Rev. 2017, 77, 169-181. [CrossRef]

143. Group of Companies “Titan”. Available online: http://www.titan-group.ru/about/ (accessed on 21 August 2019).

144. Osmakova, A.; Kirpichnikov, M.; Popov, V. Recent biotechnology developments and trends in the Russian Federation. New Biotechnol. 2018, 40, 76-81. [CrossRef]

145. ETB “Catalytic Technologies”. Available online: http://www.etbcat.com/technology/ (accessed on 17 August 2019).

146. Proskurina, S.; Heinimö, J.; Mikkilä, M.; Vakkilainen, E. The wood pellet business in Russia with the role of North-West Russian regions: Present trends and future challenges. Renew. Sustain. Energy Rev. 2015, 51, 730-740. [CrossRef] 
147. Resolution of the Government of Russia No. 1989-p of September 20, 2018 “On Approval of the Timber Complex of Russia Development Strategy until 2030". Available online: http://government.ru/docs/34064/ (accessed on 15 March 2019).

148. Rakitova, O.; Kholodkov, V. Final Report of the Pellet Market and Wood Resources in the North-West of Russian; Baltic 21 Lighthouse Project, the Baltic Sea Bioenergy Promotion Project; Biocenter: Saint-Petersburg, Russia, 2009.

149. Pirus, M. Working on the future: Congress and exhibition "Biomass: Fuel and energy". Lesprominform 2018, 4, 134-137.

150. Committee on the Fuel and Energy Complex of the Leningrad Region. Available online: http://power.lenobl. ru/o-komitete/informatsionnye-sistemy/modul-gis-energoeffektivnost/ (accessed on 21 July 2019).

151. The Renewable Materials Company “STORAENSO". Available online: https://www.storaenso.com/ (accessed on 20 July 2019).

152. INFOBIO. News Reports "Annually in the Arkhangelsk Region Introduced by Several Biofuel Boiler Houses". Available online: http://www.infobio.ru/news/4577.html (accessed on 19 July 2019).

153. Resolution of the Arkhangelsk Region Government of October 15, 2013 No. 487-pp “On Approval of the State Program of the Arkhangelsk Region "Development of Energy and Housing and Communal Services of the Arkhangelsk Region (2014-2024)". Available online: http://docs.cntd.ru/document/462608457 (accessed on 14 June 2019).

154. INFOBIO. News Reports “One More Pellet Production to Appear in Irkutsk Region”. Available online: http://www.infobio.ru/news/4586.html (accessed on 4 August 2019).

155. INFOBIO. News Reports "In the Territory of the Krasnoyarsk Region Biofuels Apply to 41 Boiler". Available online: http://www.infobio.ru/news/4589.html (accessed on 4 August 2019).

156. Perederyi, S. And again about torrefaction. Borreal BioEnergy sawmill acquires for the production of black pellets. Lesprominform 2019, 4, 148-149.

157. ROSTEPLO. Biogas Station “Luchki” Showed Historic Maximum Power Generation. Available online: http:// www.rosteplo.ru/news/2018/02/20/1519067728-biogazovaya-stanciya-luchki-pokazala-istoricheskij (accessed on 15 June 2019).

158. Resolution of the Belgorod Region Governor No. 52 of April 25, 2018 “On Approval of the Scheme and Program for the Development of the Electric Power Industry of the Belgorod Region for 2019-2023". Available online: http://publication.pravo.gov.ru/Document/View/3100201804280001 (accessed on 14 June 2019).

159. Akimova, V.V. Institutional factor of renewable energy development in the Belgorod Region. Bull. Mosc. Univ. (Ser. 5 Geogr.) 2017, 6, 18-24.

160. Decree of the Belgorod Region Government No. 427-pp of October 29, 2012 “On Approving of the Long-Term Target Program “Development of Renewable Energy Sources for 2013-2015 and for the Period until 2020". Available online: http://base.garant.ru/26350607/ (accessed on 14 June 2019).

161. Decree of the Belgorod Region Government No. 475-pp of November 25, 2013 "On Amendments to the Belgorod Region Government No. 427-pp of October 29, 2012". Available online: http://docs.cntd.ru/document/ 428669040\#loginform (accessed on 14 June 2019).

162. Order of the Belgorod Region Government No. 574-rp of December 8, 2014 “On Approving the Concept for the Development of Small Distributed Energy in the Belgorod Region until 2025". Available online: http://altenergo-nii.ru/docs/574-rp.pdf (accessed on 14 June 2019).

163. Decree of the Head of the Administration of the Tambov Region of April 25, 2018 No. 107 “On Approval of the Concept and Program of Electric Energy development in Tambov Region in 2019-2023". Available online: http://gkh.tmbreg.ru/DOC/Pravo/2018/PGAO_107.pdf (accessed on 14 June 2019).

164. Joint Stock Company “Biokhim” (JSC “Biokhim”). Available online: http://biohim68rsk.ucoz.ru (accessed on 14 May 2019).

165. Decree of the Lipetsk Region Administration No. 319 of April 23, 2018 “On the Approval of Schemes and Programs for the Development of the Electric Power Industry of the Lipetsk region for 2019-2023". Available online: http://publication.pravo.gov.ru/Document/View/4800201804250001 (accessed on 14 June 2019).

166. Lang-Yona, N.; Kunert, A.T.; Vogel, L.; Kampf, C.J.; Bellinghausen, I.; Saloga, J.; Schink, A.; Ziegler, K.; Lucas, K.; Schuppan, D.; et al. Fresh water, marine and terrestrial Cyanobacteria display distinct allergen characteristics. Sci. Total Environ. 2018, 612, 767-774. [CrossRef] [PubMed] 
167. Singh, R.; Parihar, P.; Singh, M.; Bajguz, A.; Kumar, J.; Singh, S.; Singh, V.P.; Prasad, S.M. Uncovering Potential Applications of Cyanobacteria and Algal Metabolites in Biology, Agriculture and Medicine: Current Status and Future Prospects. Front. Microbiol. 2017, 8, 515. [CrossRef] [PubMed]

168. Luan, G.; Lu, X. Tailoring cyanobacterial cell factory for improved industrial properties. Biotechnol. Adv. 2018, 36, 430-442. [CrossRef]

169. Taparia, T.; Mvss, M.; Mehrotra, R.; Shukla, P.; Mehrotra, S. Developments and challenges in biodiesel production from microalgae: A review. Biotechnol. Appl. Biochem. 2016, 63, 715-726. [CrossRef]

170. Chena, J.; Li, J.; Dong, W.; Zhang, X.; Tyagi, R.D.; Drogui, P.; Surampalli, R.Y. The potential of microalgae in biodiesel production. Renew. Sustain. Energy Rev. 2018, 90, 336-346. [CrossRef]

171. Mathimani, T.; Baldinelli, A.; Rajendran, K.; Prabakar, D.; Matheswaran, M.; Van Leeuwen, R.P.; Pugazhendhi, A. Review on cultivation and thermochemical conversion of microalgae to fuels and chemicals: Process evaluation and knowledge gaps. J. Clean. Prod. 2019, 208, 1053-1064. [CrossRef]

172. Collotta, M.; Champagne, P.; Mabee, W.; Tomasoni, G. Wastewater and waste $\mathrm{CO}_{2}$ for sustainable biofuels from microalgae. Algal Res. 2018, 29, 12-21. [CrossRef]

173. Antonov, I.A.; Kotelev, M.S.; Afonin, D.S.; Gushin, P.A.; Ivanov, E.V. Isoprenoids oil of microalgae hydrocracking with production of winter and arctic diesel fuels. Bashkir Chem. J. 2012, 19, 170-172.

174. Knoot, C.J.; Ungerer, J.; Wangikar, P.P.; Pakrasi, H.B. Cyanobacteria: Promising biocatalysts for sustainable chemical production. J. Biol. Chem. 2018, 293, 5044-5052. [CrossRef]

175. Singh, G.; Patidar, S.K. Microalgae harvesting techniques: A review. J. Environ. Manag. 2018, 217, 499-508. [CrossRef] [PubMed]

176. Kopylov, A.; Romanenko, A.V.; Zabotkina, E.A.; Mineeva, N.M.; Krylova, I.N.; Maslennikova, T.S. Picocyanobacteria in eutrophic reservoirs of the Middle Volga: Abundance, production, viral infection. Zhurnal Obs. Biol. 2014, 75, 234-244.

177. Sidelev, S.I.; Fomichev, A.A.; Babanazarova, O.V.; Zubishina, A.A. The detection of microcystin-producing Cyanobacteria in the Upper Volga watersheds. Mikrobiologiia 2013, 82, 370-371. [PubMed]

178. Korneva, L.G. Invasions of alien species of planktonic algae into Holarctic freshwaters (review). Russ. J. Biol. Invasions 2014, 1, 5-33.

179. Yoshida, M.; Yoshida, T.; Kashima, A.; Takashima, Y.; Hosoda, N.; Nagasaki, K.; Hiroishi, S. Ecological dynamics of the toxic bloom-forming cyanobacterium Microcystis aeruginosa and its cyanophages in freshwater. Appl. Environ. Microbiol. 2008, 74, 3269-3273. [CrossRef] [PubMed]

180. IZVESTIYA. Dirty Story. How the Volga became the Dirtiest River in Russia? Available online: https: //iz.ru/660518/izdaleka-dolgo (accessed on 10 June 2019).

181. Zaytseva, N.V. The Problem of Development of Blue-Green Algae in the Votkinsky and Izhevsk Reservoirs. Mod. Sci. Res. Innov. 2014, 6. Available online: http://web.snauka.ru/issues/2014/06/36048 (accessed on 16 May 2019).

182. Passport of Federal Project "Improving the Volga". 2018. Available online: http://www.minstroyrf.ru/docs/ 17662/ (accessed on 17 July 2019).

183. Ho, S.-H.; Chen, Y.-D.; Qu, W.-Y.; Liu, F.-Y.; Wang, Y. Chapter 8-Algal culture and biofuel production using wastewater. In Biomass, Biofuels, Biochemicals, Biofuels from Algae, 2nd ed.; Pandey, A., Chang, J.-S., Soccol, C.R., Lee, D.-J., Chisti, Y., Eds.; Elsevier: Amsterdam, The Netherlands, 2019; pp. 167-198.

184. Guieysse, B.; Borde, X.; Munoz, R.; Hatti-Kaul, R.; Nugier-Chauvin, C.; Patin, H.; Mattiasson, B. Influence of the initial composition of algal-bacterial microcosms on the degradation of salicylate in a fed-batch culture. Biotechnol. Lett. 2002, 24, 531-538. [CrossRef]

185. Milyutkin, V.A.; Borodulin, I.V.; Agarkov, E.A.; Rozenberg, G.S.; Kudinova, G.E. Technical Solution for Processing Blue-Green Algae in Biofuel. In Proceedings of the 35th Anniversary of the Volga Basin Institute of Ecology of the Russian Academy of Sciences and the 65th Anniversary of the Kuibyshev Biological Station “Ecological Problems of Large River Basins”, Togliatti, Russia, 15-19 October 2018; Rozenberg, G.S., Saksonov, S.V., Eds.; Anna: Togliatti, Russia, 2018.

186. Milyutkin, V.A.; Topelkin, S.A.; Borodulin, I.V.; Agarkov, E.A. Renewable Energy Sources (REn)—Biofuels from the Blue-Green Algae Biomass-Cyanobacteria. In Proceedings of the II All-Russian (National) Scientific and Practical Conference "Priority Areas of Energy Development in the Agro-Industrial Complex", Kurgan, Russia, 22 February 2018; Sukhanova, S.F., Maltsev, T.S., Eds.; Kurgan State Agricultural Academy: Kurgan, Russia, 2018. 
187. ECOVOLGA. Development of Unified Cyanobacteria Database in Saratov Storage Reservoir. Available online: http://ecovolga.com/ (accessed on 10 June 2019).

188. Olabi, A.G. Circular economy and renewable energy. Energy 2019, 181, 450-454. [CrossRef]

189. Moraga, G.; Huysveld, S.; Mathieux, F.; Blengini, G.A.; Alaerts, L.; Van Acker, K.; De Meester, S.; Dewulf, J. Circular economy indicators: What do they measure? Resour. Conserv. Recycl. 2019, 146, 452-461. [CrossRef]

190. Svensson, N.; Funck, E.K. Management control in circular economy. Exploring and theorizing the adaptation of management control to circular business models. J. Clean. Prod. 2019, 233, 390-398. [CrossRef]

191. Laso, J.; García-Herrero, I.; Margallo, M.; Bala, A.; Fullana-i-Palmer, P.; Irabien, A.; Aldaco, R. LCA-Based Comparison of Two Organic Fraction Municipal Solid Waste Collection Systems in Historical Centres in Spain. Energies 2019, 12, 1407. [CrossRef]

192. Ratner, S.V. Circular economy: Theoretical bases and practical applications in the regional economy and management. Innovations 2018, 9, 29-37.

193. Trabelsi, A.; Elouedi, Z.; Lefevre, E. Decision tree classifiers for evidential attribute values and class labels. Fuzzy Set Syst. 2019, 366, 46-62. [CrossRef]

194. Dunjic, S.; Pezzutto, S.; Zubaryeva, A. Renewable energy development trends in the Western Balkans. Renew. Sustain. Energy Rev. 2016, 65, 1026-1032. [CrossRef]

195. Parchomenko, A.; Nelen, D.; Gillabel, J.; Rechberger, H. Measuring the circular economy-A Multiple Correspondence Analysis of 63 metrics. J. Clean. Prod. 2019, 210, 200-216. [CrossRef]

196. Avdiushchenko, A.; Zając, P. Circular Economy Indicators as a Supporting Tool for European Regional Development Policies. Sustainability 2019, 11, 3025. [CrossRef]

(C) 2019 by the author. Licensee MDPI, Basel, Switzerland. This article is an open access article distributed under the terms and conditions of the Creative Commons Attribution (CC BY) license (http://creativecommons.org/licenses/by/4.0/). 